\title{
Nazi Almanya'sında Yayıncılık, Nazizm İdeolojisinin Yaydığı Anti-Semitist Söylemlerin İnşası ve Kitapların Propaganda Amaçlı Kullanımı
}

\author{
The Publishing in Nazi Germany, The Construction of Anti-Semitist Discourses \\ Spread by the Nazism Ideology and the Use of Books for the Purpose of Propaganda
}

\author{
Ebru Gülbuğ Erol*
}

\section{$\ddot{O}_{z}$}

30 Ocak 1933 tarihinde Nazilerin Almanya'da iktidara gelişi, ülkede yayıncılık alanında radikal değişimlerin yaşanmasına neden olmuştur. Nazi rejimi, kendileri için tehdit olarak değerlendirdikleri yayınları sansürlemiş, diğer yandan ülkedeki kütüphaneler üzerinde sıkı bir denetim uygulamıştır. Nazilerin, Almanya'daki yayıncılık üzerindeki etkisi, Alman Öğrenci Birliği’nin (Deutsche Studentenschaft, DSt) katılımında gerçekleşen kitap yakma (Bücher verbrennung) kampanyasiyla simgeleşmiştir. Nazilerin kitap yakma kampanyasında, zararlı olarak nitelendirilen veya Nazizm ideolojisine karşıt ideolojileri temsil eden kitaplar hedef alınmıştır. Nazizm ideolojisine karşıt yayınların ortadan kaldırılmasının yanında Nazizm ideolojisini yücelten ve fikirlerinin Alman toplumu tarafindan benimsenmesini amaçlayan yayınlar da ortaya çıkmıştır. Bu yayınlar içerisinde Nazizm ideolojisinin antisemitist söylemlerinin yer aldığ kitaplar da olmuştur. Çalışmada Nazi rejiminin, Nazizm ideolojisinin antisemitist söylemlerinin kitlelere benimsetilmesinde kitapları propaganda amaçlı nasıl kullandığı Yeşil Fundalıkta Tilkiye ve Yemininde Yahudiye Güvenme (Traukeinem Fuchs auf grüner Heid und keinem Jud auf seinem Eid) adlı kitap özelinde ele alınmıştır. Çalışma kapsamında kitapta yer alan görsel ve yazll göstergeler, Karl Bühler'in Organon Modeli ve Claude Lévi-Strauss'un İkili Karşıtlıklar Modeli özelinde göstergebilim yöntemi kullanılarak incelenmiştir. Çalışmada kitapta Yahudilerin Alman toplumunda istenmeyen kişiler olduğuna, ötekileştirildiklerine ve dışlandıklarına yönelik algıların meydana getirildiği sonucuna ulaşılmıştır. Bu şekilde elde edilen bulgular ışığında kitap üzerinden Nazizm ideolojisine ait antisemitist söylemlerin Alman toplumunda benimsetilmeye çalışıldığına yönelik çıkarımda bulunulmaktadır.

Anahtar Sözcükler: Kitap; antisemitizm; Nazizm; ideoloji; propaganda; Almanya.

\begin{abstract}
The rise of the Nazis to power in Germany on 30 January 1933 caused radical changes in the field of publishing in the country. The Nazi regime censored publications that they considered a threat to them, while exercising strict control over libraries in the country. The influence of the Nazis on publishing in Germany was symbolized by the bookburning (Bücher verbrennung)
\end{abstract}

\footnotetext{
*Prof. Dr., Alanya Hamdullah Emin Pasa University. E-posta: egerol@ahep.edu.tr

Prof. Dr., Alanya Hamdullah Emin Paşa University
}

Geliş Tarihi-Received: 30.10 .2020

Kabul Tarihi - Accepted: 13.12 .2020 
campaign, which took place with the participation of the German Student Union (Deutsche Studenten schaft, DSt). The Nazis' book burning campaign targeted boks that were considered harmful or represented ideologies opposed to the Nazism ideology. In addition to the elimination of publications opposed to the Nazismi deology, publications that glorified the Nazism ideology and aimed at the adoption of the ideas of the Nazism ideology to the German society appeared. Among these publications, there were also books in which the anti-Semitist discourses of the Nazism ideology were included. In the study, how the Nazi regime used the boks for the purpose of propaganda in the adoption of the anti-Semitic discourses of the Nazism ideology to them as was examined in the book called Trau keinem Fuchs auf grüner Heid und keinem Jud auf seinem Eid (Trust No Fox on his Green Heath and No Jew on his Oath). Within the scope of the study, the visual and written indicators in the book were analyzed by using the semiotics method in the context of Karl Bühler's Organon Model and Claude Lévi-Strauss' Binary Contrasts Model. In the study, it was concluded that the perceptions that Jews were unwanted, marginalized, excluded in German society were created. In the light of the findings obtained in this way, it can be inferred that the anti-Semitist discourses of the Nazism ideology are adopted in German society.

Keywords: Book; antisemitism; Nazism; ideology; propaganda; Germany.

\section{Giriş}

Nazi rejimi, Alman halkı üzerinde sıkı bir denetim elde etmek ve Nazizm'in ideolojik söylemlerinin kitleler tarafından benimsenmesini sağlamak için medya üzerinde kontrol kurmayı amaçlamıştır. Bu amaçla Nasyonal Sosyalist Alman İşçi Partisi'nin (NSDAP) önde gelen isimlerinden Dr. Joseph Goebbels'in liderliğinde Halkı Aydınlatma ve Propaganda Bakanlığı kurulmuştur. Goebbels bakanlığı döneminde Alman medyası üzerinde sıkı denetim kurmuş, Nazi rejimi için tehdit olarak değerlendirilen yayınlara izin vermemiştir. Nazi rejimi tarafından uygulanan sansür, her türlü muhalif yayının Alman halkıyla buluşmasını önlemiştir. Sansür yoluyla Naziler, karşıt fikirlerin Alman toplumunda güç kazanmasına izin vermemiş, Alman toplumunda Nazizm ideolojisini egemen kılmaya çalışmıştır. Bu süreçte Almanya'da kitap yayıncılığı ve kütüphaneler de doğrudan Nazilerin denetimi altına girmiş ve yayıncılık alanında Franz Eher Nachfolger ön plana çıkmıştır. Franz Eher Nachfolger GmbH, NSDAP'nin merkezi yayınevi rolünü üstlenmiş ve Nazi Almanyası döneminde en büyük kitap ve süreli yayın şirketlerinden biri haline gelmiştir. Nazi Almanya'sında başlıca gazetelerden olan Völkischer Beobachter ${ }^{l}$ n basımdan sorumlu olmuştur. Adolf Hitler'in Mein Kampf kitabı da yine bu yayınevi tarafından yayınlanmıştır. Nazi rejiminin yayın hayatına hakim olmasıyla birlikte ülkede Nazizm ideolojisini konu alan yayınlar ön plana çıkmaya başlamıştır. Bu yayınlarda Nazizm ideolojisinin yüceltilmesine ve Hitler'in liderlik kültünün inşa edilmesine çalışılmıştır. Nazizm ideolojisinin antisemitist öğretileri de yayınlar üzerinden kitlelere sunulmuştur. $\mathrm{Bu}$ aşamada Nazi Almanya'sında uygulanan sansür, Nazizm ideolojisinin antisemitist söylemlerine karşı çıkan yayınların Alman halkına ulaşmasını engellemiştir.

\footnotetext{
${ }^{1}$ VölkischerBeobachter (Halkın Gözlemcisi), 1920-1945 yılları arasında DasReich ve Der Stürmer ile birlikte NSDAP'nin resmi gazetesi, aynı zamanda Nazi Almanyası'nın ana gazetelerinden biridir. Gazete, NSDAP için haber ajansı olarak hareket etmiştir (Dussel, 2019, s.448).
} 
Nazi Almanya'sında Yayıncılık, Nazizm İdeolojisinin Yaydığı Anti-Semitist Söylemlerin İnşası ve Kitapların Propaganda Amaçlı Kullanımı

The Publishing in Nazi Germany, The Construction of Anti-Semitist Discourses Spread by the Nazism Ideology and the Use of Books for the Purpose of Propaganda

Kitap sansürünü inceleyen alanda çeşitli akademik çalışmalar yer almaktadır. (Lowenthal, 1959; Gillotti, 1962; Boyer, 1963; Fiske ve Lowenthal, 1968; Roncelli, 1983; Biagioli, 2002; Connelly, 2009; Barnes, 2014; Sabato, 2014). Diğer yandan belirli konular bağlamında kitap ve kütüphane konusunda sansürü ele alan çalışmalarda bulunmaktadır. $\mathrm{Bu}$ çalışmalar içerisinde de:

- Smith (1955): kitap sansürünün anayasal yönlerini;

- Hogan (1967): kitap seçimi ve sansürü;

- Edwards (1981): okul kitapları sansürünü;

- Stielow (1983): Amerikan kütüphaneleri ve sansürü;

- Ficociello (1984): sansür ve kitap seçimini;

- Dunn (1984): Okul kütüphanesi sansürü tartışmalarını;

- Reimer ve Brock (1988): kitaplar, öğrenciler ve sansürü;

- Selth (1993), Oppenheim ve Smith (2004): kütüphanelerde sansürü;

- Stover (1994): kütüphaneler ve sansürü;

- Ekholm (2001): Fin kütüphanelerinde 1944 yılından 1946 yılına kadar siyasi sansürü;

- Stelmakh (2001): Sovyetler Birliğgi'nde sansür bağlamında okumayı;

- Boyer (2002): Amerika'da kitap sansürünü;

- Foerstel (2002): okullarda ve halk kütüphanelerinde kitap sansürü;

- Duthie (2010): kütüphaneler ve sansür etiğini;

- Ravenwood ve Feather (2010): 1919-1939 yılları arasında İngiliz halk kütüphaneciliğinde sansür ve kitap seçimini;

- Urrieta ve Machado-Casas (2013), şehir okullarında kitap yasağı ve sansürü;

- Kidman (2015): 1954 yılında sansür ve çizgi roman endüstrisini;

- Carlson (2018): devlet okullarında kitap sansürüne karş1 savunuculuğu incelemektedir.

Kitap sansürünü inceleyen bu tür akademik çalışmalar, egemen güçlerin iktidarlarına yönelik muhalefeti önlemek amacıyla yayıncılık konusunda nasıl bir yol izlediklerine 1şık tutabilmektedir.

Sansürü Nazi Almanya'sı özelinde inceleyen akademik çalışmalar da bulunmaktadır. Bu çalışmalar içerisinde de; Panse (1996), Nazi Almanya'sında sansürü; Bosmajian (1986), Nazi Almanya'sında sansür ve mitolojiyi; Zuschlag (1997), Nazi Almanya'sında görsel sanatlarda sansürü; Sturge (2002), Nazi Almanya'sında kurguya yönelik sansürü; Levi (2004), 1918-1945 y1lları arasında Almanya'da müzikal modernizmin sansürünü; Lewy (2016), Nazi Almanya'sında kitap sansürünü ele almaktadır. Nazi Almanya'sında sansürü ele alan çalışmalarda, muhalif yayınların önüne geçilerek, Nazi rejiminin ideolojik söylemlerinin ön plana çıkarılması ve kitlelere benimsetilmesi süreci hakkında kapsamlı bilgiye ulaşılabilmektedir.

Nazilerle ilişkili antisemitizm konusunu inceleyen çeşitli çalışmalar bulunmaktadır (Thurlow, 1984; Geehr vd., 1985; Brackman, 2000; Heilbronner, 2004; Eldridge, 2006; Lackey, 2011). Bu çalışmalar içerisinde:

- Hausheer (1936): Nazi antisemitizminin sosyo-ekonomik arka planını; 
- Delfiner (1971): Sovyet ve Nazi antisemitizmini;

- Littel (1971): Alman kilise mücadelesi ve Nazi antisemitizmini;

- Mieder (1982): Nazi Almanya'sında atasözleri ve antisemitizmin folklor yoluyla yayılmasinı;

- Kater (1984): Savaş öncesi Nazi Almanya'sında günlük antisemitizmi;

- Hartmann (1984): Keogh (2006), antisemitizm ve Nazizm'i;

- Bankier (1987): 1933-1938 yılları arasında Alman Komünist Partisi ve Nazi antisemitizmini;

- Kushner (1989): 1933-39 yılları arasında Nazi antisemitizmine İngiliz tepkilerini;

- Heilbronner (1990): Nazi Partisi'nin faaliyet ve propagandasında Nazi antisemitizminin rolünü;

- Samuels vd. (1993): Antisemitizm ve Nazileri;

- Bergen (1994): Nazi Almanya'sinda Katolikler, Protestanlar ve Hiristiyan antisemitizmini;

- Bergen (1994): Nazi Volksdeutsche kavramı ve Doğu Avrupa'da antisemitizmi;

- Smith (1998): Antisemitizm ve Nazizm ideolojisini;

- Beck (2006): Nazilerin iktidarı ele geçirmesi sırasında antisemitizmi;

- Herf (2006): Nazi Almanya'sı, İkinci Dünya Savaşı sırasında antisemitizm ve antiSiyonizm'i;

- Steinweis (2006): Nazi Almanya'sında bilimsel antisemitizmi;

- Bacharach (2007): Nazi ideolojisinde antisemitizm ve ırkçılığı;

- Niven (2010): Doğu Almanya'da Nazi antisemitizminin hatırlanmasıni;

- Voigtländer ve Voth (2012): Nazi Almanya'sındaki antisemitist şiddetin ortaçağ kökenlerini;

- Seul (2013): Nazi antisemitizmine İngiliz ve Amerikan basın tepkilerini;

- Wegner (2014): Nazi Almanya'sında antisemitizm ve okullaşmay1;

- Shain (2015): 1930'lar ve 1940'lar boyunca Güney Afrika'da Nazi Antisemitizminin yankılarını;

- Frosh (2015): Antisemitizm, Nazizm ve psikanalizi;

- Ribbens (2018): Nazi işgali altındaki Hollanda'da antisemitizmi:

- Weinstein (2019): Nazi Almanya'sında film komedisinde antisemitizmi;

- Nelson (2020): Antisemitizm ve Nazi şiirini incelemektedir.

Naziler ve antisemitizm üzerine geniş bir yelpazede akademik çalışmanın yürütülmesinin çeşitli nedenleri bulunabilmektedir. Bunlardan biri Naziler tarafından ön plana çıkarılan Nazizm ideolojisinin antisemitist öğretileri, diğeri de Nazi Almanya'sındaki antisemitist uygulamalar olabilmektedir.

Ulusal çalışmalar içerisinde son dönemde Nazi Almanya'sındaki propaganda faaliyetlerini göstergebilim yöntemi kullanarak inceleyen alanda bazı çalışmalar bulunmaktadır. Bu çalışmalar içerisinde: Çakı (2019), Nazi Almanya'sında propaganda posterlerinde Yahudi karşııtı söylemleri Roland Barthes'ın mit kavramından hareketle; Çalışkan (2020) Nazi Almanya'sı işgali altındaki Sırbistan'da Komünizm karşıtı kullanılan propaganda posterlerini Charles Sanders Peirce'ün; Gülada vd. (2019), Nazi Almanya'sında ulusal 
Nazi Almanya'sında Yayıncılık, Nazizm İdeolojisinin Yaydığı Anti-Semitist Söylemlerin İnşası ve Kitapların Propaganda Amaçlı Kullanımı

The Publishing in Nazi Germany, The Construction of Anti-Semitist Discourses Spread by the Nazism Ideology and the Use of Books for the Purpose of Propaganda

seferberlik propagandasını Barthes'ın; Keskin Yılmaz vd. (2020), Nazi Almanya'sında antisemitist mitlerin eğitime yansımasını Charles William Morris'in göstergebilim anlayışı üzerinden analiz etmiştir.

Ulusal literatür içerisinde farklı ideolojilerin propaganda faaliyetlerini göstergebilim yöntemi kullanarak inceleyen alanda çeşitli çalışmalar bulunmaktadır. Bu alandaki çalışmaların büyük bir kısmının konulu sinema filmleri fakat önemli bir bölümünün de posterler üzerinden gerçekleştirildiği ortaya çıkmaktadır. Çalışmada ise diğer çalışmalardan farkı olarak doğrudan Nazi Almanya'sında yayıncılık, antisemitizm ve propaganda konuları üzerinde durulmakta ve kitap üzeriden göstergebilim yöntemi kullanılmaktadır. Bu aşamada çalışmada Nazizm ideolojisindeki antisemitist söylemler özelinde Nazi Almanya'sında yayıncılık alanında Nazizm ideolojisinin yansımalarının ortaya konulması amaçlanmıştır. Bu amaçla çalışma kapsamında Nazi Almanya'sı döneminde yayınlanan Yeşil Fundalıkta Tilkiye ve Yemininde Yahudiye Güvenme (Trau keinem Fuchs auf grüner Heid und keinem Jud auf seinem Eid) adlı antisemitist kitap göstergebilim yöntemi kullanılarak incelenmiştir.

Çalışmada aşağıda yer alan sorunların cevaplandırılması hedeflenmiştir;

- Nazizm ideolojisindeki antisemitist söylemler kitapta ne şekilde yansıtılmaktadır?

- Kitapta hangi görsel ve yazilı kodlar üzerinden Yahudiler temsil edilmektedir?

- Kitap üzerinden Alman toplumunda hangi Yahudi karşıtı mitlerin oluşturulmasına çalışılmaktadır?

- Kitapta Alman vatandaşları ve Yahudiler arasında hangi soyut kavramlar üzerinden karşılaştırma yapılmaktadır?

Çalışma, Nazi Almanya'sı döneminde yayıncılık konusunda bilgi vermesi ve Nazizm ideolojisinin kitleler tarafindan benimsetilmesinde kitabın propaganda amaçlı kullanımını açıklaması bakımından önem taşımaktadır. Çalışmada elde edilen bulgular ışı̆̆ında ideolojik söylemler boyutunda kitapların propaganda amaçlı ne şekilde kullanabildiğine ışık tutulması amaçlanmaktadır.

\section{Nazi Almanya'sında Muhalif Kitaplara ve Kütüphanelere Müdahale}

Nazilerin, 1933 yılında Almanya'da iktidara gelişi, Weimar Cumhuriyeti²'ndeki özgürlük havasının ortadan kalkmasında ve beraberinde ülkede 12 yıl kesintisiz uygulanacak sıkı bir sansür döneminin de başlamasına neden olmuştur. Nazi Almanya'sında kurulan Halkı Aydınlatma ve Propaganda Bakanlığı, yalnızca gazete ve dergi gibi basılı yayınlar üzerinde değil, aynı zamanda müzik, radyo yayını, film gibi geniş bir yelpazede sansür uygulamasına yönelmiştir. Nazilerin sansür uygulaması kitaplar üzerinde ise, farklı bir boyuta taşınmıştır. Naziler, bazı yazarların kitaplarını kendileri için önemli bir tehdit olarak değerlendirmiş ve bu nedenle tehdit olarak değerlendirilen kitaplara yönelik doğrudan müdahalede bulunulmuştur. $\mathrm{Bu}$ aşamada Naziler, bu kitapları önce toplatmış ve ardından geniş halk kitlelerinin katılımıyla

\footnotetext{
${ }^{2}$ Weimar Cumhuriyeti (Weimarer Republik), Almanya'da 9 Kasım 1918- 23 Mart 1933 tarihleri arasında var olan cumhuriyete verilen isimdir. Weimar Cumhuriyeti'nin yıkılmasından sonra Almanya'da Nazilerin liderliğinde Üçüncü Reich (Drittes Reich) kurulmaktadır. 30 Ocak 1933 tarihinde Hitler'in şansölye olmasıyla (Kershaw, 2007, s. 439), zaman içerisinde Almanya'da cumhuriyet yönetimi yerine totaliter bir yönetim oluşmaktadır.
} 
yakmıştır. Kitap yakma eyleminde Berlin şehri ön plana çıkmıştır. 10 Mayıs 1933 tarihinde, Berlin'deki Opernplatz'da, Alman öğrenci dernekleri birkaç haftalık planlamanın sonucu olarak ayrıntılı bir kitap yakma ritüeli düzenlemiştir. Çok sayıda öğrenci fener ışığı geçidiyle meydana çıkmış, kitaplarla dolu ahşap iskele ateşe verilmiştir. O gece ve sonraki hafta, Almanya'daki üniversite kentlerinde benzer etkinlikler düzenlenmiş ve bunların çoğu, yürüyüşler, meşaleler ve konuşmalar dahil olmak üzere açıkça Berlin modelini izlemiştir (Fishburn, 2008, s. 31).

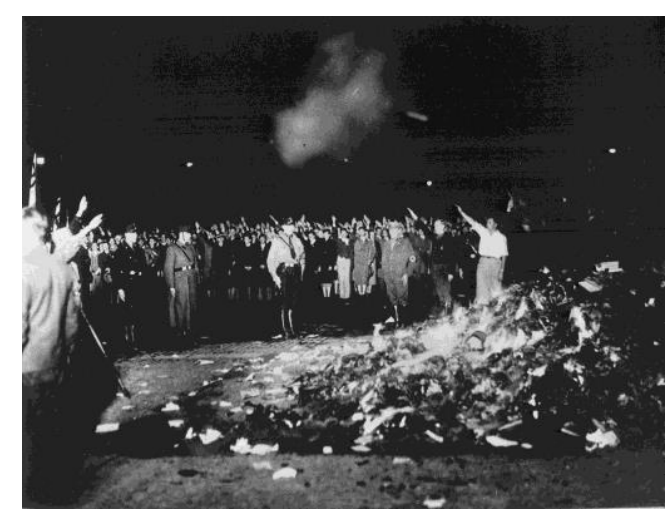

Resim 1. Naziler Tarafından Kitapların Yakılması (Bundesarchiv, 2020).

Nazi rejimi Almanya'da hangi kitapların okunacağı, hangi kitapların okunmayacağı konusunda doğrudan belirleyici olmaya çalışmıştır. Bu aşamada sansürün dışında toplu kitap yakma kampanyasıyla Nazi Almanya'sında muhalif kitapların etkinliğinin kırılması amaçlanmıştır. Yakılan kitaplar içerisinde anarşist, sosyalist, komünist, liberal ve Yahudi yazarların kitapları yer almıştır. Karl Marx da hedef alınan yazarlar içerisinde olmuştur. Kitap yakma eylemlerinde ise Alman olmayan ruha karşı eylem (Aktionwider den undeutschenGeist) söylemi ön plana çıkarılmıştır. Bu şekilde Nazi Almanya'sında Nazizm ideolojisi ve Nazi rejimi için tehdit oluşturabilecek her türlü yayının ortadan kaldırılmasına çalışılmıştır. Aynı zamanda Nazilerin kitap yakma kampanyası, Nazi rejiminin muhaliflerine yönelik gövde gösterisi haline gelmiştir. Goebbels'in kendisi de kitapların yakılmasına güçlü bir sembolik eylem olarak değinmiştir (Ritchie, 1988, s. 638).

Nazilerin Alman olmayan ruha karşı eylem'i özellikle öğrenciler üzerinde yoğunlaşmıştır. Her öğrencinin kendi kütüphanesini ve aynı zamanda arkadaşlarının kütüphanesini "zararlı" olarak nitelendirilen kitaplardan arındırması teşvik edilmiştir. Bununla da yetinilmeyip üniversite, enstitü ve halk kütüphaneleri de araştırılmıştır. Kütüphaneci Wolfgang Herrmann'ın Kara Listeler'i (Schwarzen Listen) üzerinden yakılacak kitaplar belirlenmiştir. Kampanya sırasında kütüphaneler müdahaleye uğramış ve kimi kitaplar toplanmıştır. Berlin'de MagnusHirschfeld'in Cinsel Araştırma Enstitüsü'ne (Institut für Sexual Wissenschaft) baskın düzenlenmiş (Bauer, 2014, s. 17) ve çok sayıda eser bulunan kütüphaneye müdahale gerçekleştirilmiştir. 


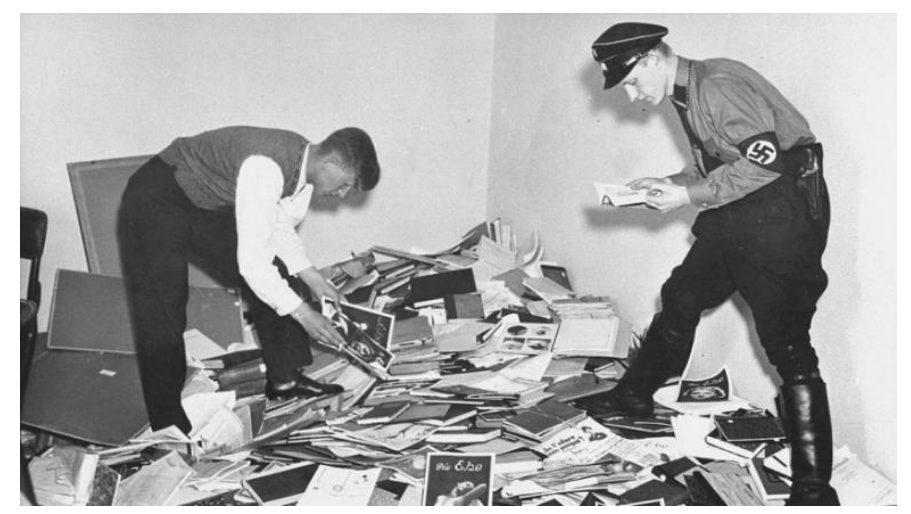

Resim 2. Berlin Cinsel Araştırma Enstitüsü Direktörü Dr. Magnus Hirschfeld'in Kütüphanesine Müdahale (USHMM, 2020).

Nazilerin kitaplara yönelik müdahalesinde özellikle Yahudi yazarlar hedef alınmıştır. Yahudi yazarların eserleri Alman toplumu için tehdit olarak değerlendirilmiş ve bu eserlere karşı doğrudan müdahalede bulunulmuştur. Almanya'nın çöküşünden sorumlu tutulan kitaplar saldırıya uğramış (Fishburn, 2007, s. 223), diğer yandan onlarca yazar yasaklanmıştır. Nazilerin kitaplara müdahalesinin yakma eylemine dönüşmesi ve bunu geniş kalabalıklar eşliğinde gerçekleştirmesi, Nazi rejiminin Nazi Almanya'sındaki yayıncılık üzerindeki etkisini doğrundan yansıtmıştır. Reichstag Yangını' 'ndan sonra Nazilerin devlet üzerinde etkiliğini arttırmaya başlaması ve zaman içerisinde NSDAP'nin Almanya'daki tek resmi parti haline gelmesi, Nazi rejiminin Almanya'daki yayıncılık üzerinde doğrudan kontrol kurmasına imkân sağlamıştır. Nazi Almanya'sının son bulduğu İkinci Dünya Savaşı’ndan sonra Nazilerin kitaplara müdahalesini simgeleyen çeşitli anıtlar oluşturulmuştur.

\section{Nazi Almanya'sında Propaganda Yayıncılı̆̆ına Genel Bakış ve Antisemitizm}

Naziler, Almanya'da gerçekleştirdikleri sıkı sansür uygulamasıyla birlikte Nazizm ideolojisini yücelten ve Nazi rejiminin kitleler üzerinde etkisini arttırmayı amaçlayan yayınlar da yapmıştır. Özellikle Nazi Almanya'sında çeşitli antisemitist yayınlar hazırlanmış ve hazırlanan yayınlar üzerinden de Yahudilere yönelik olumsuz algılar inşa edilmeye çalışılmıştır. Bu aşamada Goebbels'in antisemitist söylemlerinin ve Bolşevizm'in arkasında Yahudilerin olduğu iddialarının (Goebbels, 2016, s. 39), Nazi Almanya'sında antisemitist yayınların şekillenmesinde önemli rolünün olduğu ileri sürülmektedir.

Nazi Almanya'sında Nazi propagandasının önde gelen iki temel kitle iletişim aracı radyo ve sinema olmuştur. Her iki kitle iletişim aracı da Nazilerin propaganda faaliyetlerinde etkili bir şekilde kullanılmıştır. Naziler radyo yayıcılığının Almanya'da hızla gelişmesini ve Alman halkının önemli bir bölümünün radyoya sahip olmasını sağlamıştır. Diğer yandan Naziler, uluslararası radyo yayıncılığına da ağırlık vermiş, bu aşamada İngiltere'ye yönelik William Joyce tarafından "Lord Haw-Haw" adı verilen radyo yayınlarını gerçekleştirmiştir.

\footnotetext{
${ }^{3}$ Reichstag Yangını (Reichstagsbrand), 27 Şubat 1933 tarihinde Alman parlamento binasında çıkan yangındır (Hett, 2015, s. 199). Yangından sonra Almanya başbakanı Adolf Hitler, 23 Mart 1933 tarihinde kabul edilen Yetki Kanunu'yla (Ermächtigungsgesetz) ülkede sıkı bir denetim elde etme imkanı bulmuştur.
} 
Joyce'un radyo yayınları doğrudan propaganda içerikli olmuştur. Ayrıca Amerikalı yayıncı “Axis Sally” lakaplı Mildred Gillars da, İkinci Dünya Savaşı'nda Naziler için çalışmıştır. Diğer yandan Naziler, haber yayıncılığı alanında Die Deutsche Wochenschau (Alman Haber Filmi) adlı haber programlarını hazırlamıştır. Die Deutsche Wochenschau, 1940-1945 yı1ları arasında Nazi Almanya'sı sinemalarında yayınlanan haber yayınlarını oluşturmuştur. $\mathrm{Bu}$ haber programları üzerinden cephelerden haberler Alman halkına taşınmış ve Alman ordusunun savaşlarda kazandığı zaferler ön plana çıkarılarak Alman halkının moralinin yüksek tutulmasına çalışılmıştır. Nazilerin egemenliği kurulduktan sonra, radyo propagandası Yahudi karşıtı eylemleri kışkırtmıştır (Adena vd. 2015, s. 1885).

Naziler, radyo gibi sinemayı da etkili bir propaganda aracı olarak kullanmış, özellikle Nazizm ideolojisindeki antisemitizmin etkileri Jud Süß (1940) ve Der ewige Jude (1940) gibi yayınlarda ön plana çıkmıştır. Nazi Almanya'sı döneminde propaganda sineması önemli bir gelişme göstermiş ve çeşitli konularda propaganda filmleri hazırlatılmıştır. Bunlar içerisinde; Naziler tarafından hazırlanan belki de en etkili propaganda filmi 1935 yapımı İradenin Zaferi (Triumphdes Willens) adlı belgesel filmi olmuştur. Riefenstahl'in yönetmenliğinde hazırlanan film, NSDAP'nin Nürnberg'deki parti kongresini konu almıştır. Ayrıca yine Leni Riefenstahl yönetmenliğinde Berlin'de gerçekleştirilen 1936 Yaz Olimpiyatları'na yönelik Olympia adında propaganda filmi hazırlanmıştır. İki bölümden oluşan filme (Rodrìguez, 2003, s. 111) büyük bir bütçe ayrılmıştır.

Naziler, gazete ve dergiler üzerinden de propaganda faaliyeti yürütmüştür. Bu aşamada Nazi Almanya'sındaki gazeteler içerisinde NSDAP'nin parti gazetesi Völkischer Beobachter ön plana çıkmıştır. Völkischer Beobachter'ın dışında Goebbels tarafından kurulan Das Reich da Nazi Almanya'sında önde gelen gazetelerden biri olmuştur. Ayrıca Nazi Almanya'sında kadınlara yönelik NS-Frauen-Warte, genç kızlara yönelik Das Deutsche Mädel ve çocuklara yönelik Der Pimpf gibi dergiler de yayınlanmıştır. Nazi Almanya'sında Nazi propagandasının en sert antisemitist söylemlerinin yer aldığı gazetelerden biri ise Der Stürmer olmuştur. Der Stürmer gazetesi yer verdiği antisemitist karikatürler üzerinden Yahudilere yönelik sert eleştirilerde bulunmuştur. İkinci Dünya Savaşı'ndan sonra gazetenin yayıncısı Julius Streicher, insanlığa karşı işlediği suçlardan idam edilmiştir (Eberle ve Uhl, 2017, s. 611-612). Gazete ve dergilerin dışında Naziler, posterleri de propaganda amaçlı etkili bir şekilde kullanmıştır. Naziler tarafından hazırlanan posterlerde Yahudi karşıtı söylemlerden Hitler'in liderlik kültüne kadar geniş bir alanda propagandaya yönelinmiştir. Özellikle İkinci Dünya Savaşı sırasında propaganda posterlerinde Yahudi-Mason Komplosu ${ }^{4}$ konu olarak ele alınmıştır. Bu komplo teorisi üzerinden Yahudilerin dünya egemenliğini ele geçirmeye çalıştığı ve ABD ve Sovyetler Birliği yönetimlerinin Yahudilerin etkisinde kaldığı ileri sürülmüştür.

Nazi Almanya'sında kitap yayıncılı̆̆ı alanında da Nazilerin önemli bir etkisi olmuştur. Naziler, Nazizm ideolojisinin kitleler tarafından anlaşılması, NSDAP'nin Almanya'da hangi şartlarda ortaya çıktığının ortaya konulması ve Hitler'in siyasi fikirlerinin öğrenilmesi amacıyla Mein Kampf (Kavgam) kitabını ön plana çıkarmıştır. Hitler’in hapishanede kaldığı dönemde

\footnotetext{
${ }^{4}$ Yahudi-Mason komplosu, Yahudi ve Masonlar arasında olduğu iddia edilen gizli bir koalisyonu içeren antisemitik ve antimasonik bir komplo teorisidir. Yahudilik, Masonluk ve Marksizm de bir arada kullanılabilmektedir (VonBieberstein, 1977, s. 1).
} 
Nazi Almanya'sında Yayıncılık, Nazizm İdeolojisinin Yaydığı Anti-Semitist Söylemlerin İnşası ve Kitapların Propaganda Amaçlı Kullanımı

The Publishing in Nazi Germany, The Construction of Anti-Semitist Discourses Spread by the Nazism Ideology and the Use of Books for the Purpose of Propaganda

yazdığı Kavgam kitabı, Franz Eher Nachfolger tarafından yayınlanmıştır. Diğer yandan Nazi Almanya'sında Nazizm ideolojisinin antisemitist söylemlerinin kitleler tarafından benimsenmesi amacıyla da kitaplar ortaya çıkmıştır. Bu aşamada Alman çocuklara yönelik Der Giftpilz (Zehirli Mantar) ve Trau keinem Fuchs auf grüner Heid und keinem Jud auf seinem Eid (Yeşil Fundalıkta Tilkiye ve Yemininde Yahudiye Güvenme) adlı kitaplar yayınlanmıştır.

\section{Yöntem}

Nazi Almanya'sı döneminde antisemitist propaganda amacıyla kullanılan tüm kitaplar çalışmanın evrenini oluşturmaktadır. Bu aşamada Nazi Almanya'sında antisemitizmi konu alan iki kitap öne çıkmaktadır: Zehirli Mantar (Der Giftpilz) ve Yeşil Fundalıkta Tilkiye ve Yemininde Yahudiye Güvenme (Trau keinem Fuchs auf grüner Heid und keinem Jud auf seinem Eid). Çalışma kapsamında yapılan incelemede Zehirli Mantar kitabının farklı çalışmalarda ele alındığı ortaya çıkmıştır. Bu açıdan çalışma önceden ele alınmayan Yeşil Fundalıkta Tilkiye ve Yemininde Yahudiye Güvenme adlı kitap üzerinden gerçekleştirilmiştir. Yeşil Fundalıkta Tilkiye ve Yemininde Yahudiye Güvenme, Nazi Almanya'sında 1936 yılında basılan bir çocuk kitabıdır. Kitap, bir anaokulu öğretmeni olan Elvira Bauer tarafından yazılmış ve Der Stürmer'in de karikatüristi olan Philipp Rupprecht tarafından resimlendirilmiştir. Alman çocuklarına sözde Yahudi'nin ne olduğunu ve neye benzediğini öğretmeyi amaçlamayan kitap, Yahudilere yönelik ağır eleştirilere yer vermiştir.

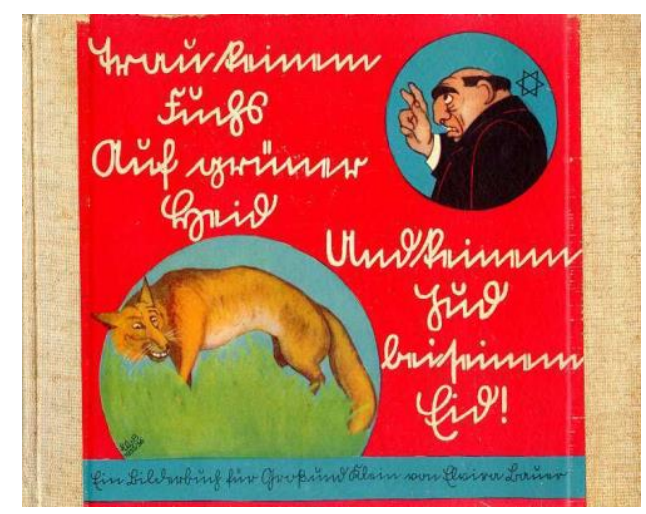

Resim 3. Kitabın Kapağı (Bauer, 1936).

Çalışmada kitapta yer alan görsel ve yazılı kodların çözümlenebilmesi için nitel araştırma yöntemlerinden göstergebilim yöntemi kullanılmıştır. Çalışma kapsamında kitaptaki edimsel boyutların ortaya konulabilmesi için Alman dilbilimci Karl Bühler'in Organon Modeli, kitaptaki ikili karşıtlıkların ve mitlerin ortaya konulabilmesi için de Fransız antropolog Claude Lévi-Strauss'un İkili Karşıtlıklar Modeli özelinde göstergebilimsel analiz gerçekleştirilmiştir. Daha kapsamlı açıklamak gerekirse çalışmada Organon Modeli'nin kullanılmasının amacı, hikaye kitabındaki görsel ve yazılı kodların hangi bağlam temelinde ortaya konulduğunun ve hangi göstergeler üzerinden antisemitist propaganda mesajlarının verildiğinin açıklanmasıdır. İkili Karşıtlıklar Modeli’nin kullanılmasının amacı ise hikaye kitabında Almanlar ve Yahudiler arasında hangi karşıtlıkların ortaya konularak, antisemitist proganda mitlerinin inşa edilmeye çalışıldığının ifade edilmesidir. 
Göstergebilim, göstergeler üzerinden oluşturulan anlamları inceleyen bir bilim dalıdır. $\mathrm{Bu}$ açıdan göstergebilimin merkezinde göstergeler yer almaktadır (Fiske, 2017, s. 122). 20. yüzyılın ilk yarısında Charles Sanders Peirce ve Ferdinand de Saussure'ün çalışmalarıyla ortaya çıkan ve farklı alanlardaki uzmanların katkılarıyla gelişen göstergebilim, günümüzde önde gelen araştırma yöntemlerinden birini oluşturmaktadır. Bühler ve Lévi-Strauss da alana yeni göstergebilim modeli kazandıran uzmanlardandır. Bühler'in Organon Modeli içerisinde Anlatımsallık işlevi (Ausdrucksfunktion), Temsil işlevi (Darstellungsfunktion) ve İstem işlevi (Appellfunktion) kavramları yer almaktadır. Anlatımsallık işlevi boyutunda göstergelerin bir araya getirilme süreci; temsil işlevi boyutunda göstergeler üzerinden verilmek istenen anlam; istem işlevi boyutunda da karşı tarafa verilen mesajın sonucunda oluşması beklenen durum açıklanmaktadır (Şekil 1).

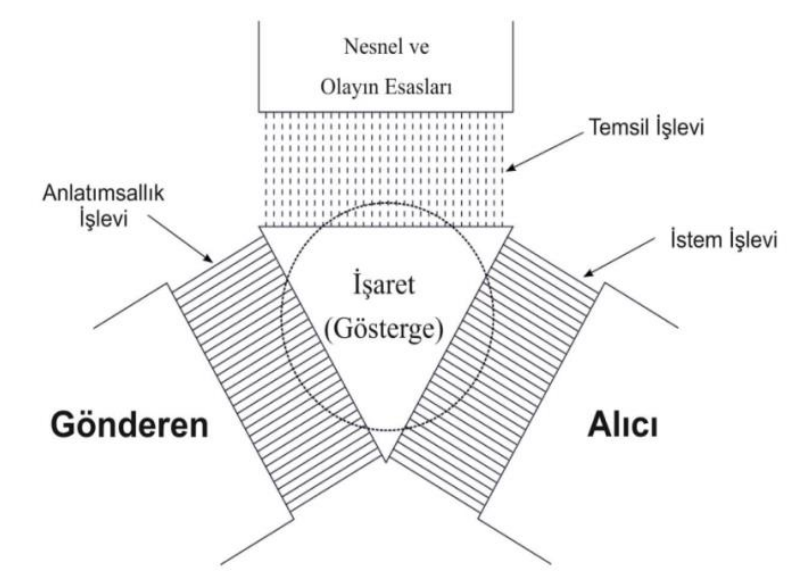

Şekil 1.Organon Modeli (Sonesson, 2016, s. 10).

Lévi-Strauss'un İkili Karşıtllklar Modeli’nde kavramlar, somut ve soyut kavramlar olarak iki farklı guruba ayrılmakta ve aralarındaki karşıtlıklar incelenmektedir. Bu aşamada somutlama mantığı üzerinden belirli somut kavramların, belirli soyut kavramlar üzerinden temsil edilmesi söz konusu olabilmektedir (Tablo 1). Oluşturulan ikili karşıtlıklarda bir tarafin diğerinden üstün olarak ortaya konulabildiğini açıklamaktadır (Lévi-Strauss, 2017, s. 70). LéviStrauss, insanların kendilerine yabancı olan düşünce, inanış ve yaşam biçimleriyle karşılaştıklarında "buna izin verilmemeliydi", "bu bizden değil” vb. tepkileri verebildiğini ileri sürmektedir (Lévi-Strauss, 2016, s. 26). Bu aşamada farklılık ikili karşıtlıkların oluşmasına yol açabilmektedir. Ayrıca Lévi-Strauss bir toplumun ilkellik sorunun da o toplumun komşularıyla oluşturduğu aykırılıklarla ifade edilebildiğini belirtmektedir (Lévi-Strauss, 2012, s. 163). Diğer bir deyişle bir toplumun kendisinden farklı bir yaşam biçimini tercih eden diğer bir toplumu "yaban” olarak değerlendirebildiği ileri sürülmektedir. Lévi-Strauss'un ikili karşıtlıklar incelemesinin dışında mit olgusu da ön plana çıkmaktadır. Lévi-Strauss'a göre mit, insanlara evreni anlayabilmeyi sağlayan bir illüzyonu ifade etmektedir (Lévi-Strauss, 2013, s. 37). LéviStrauss, mitlerin toplum düzenini meşrulaştırmak ve mevcut durumun meşruiyetini geçmişteki bir durumla temellendirmek için kullanılabildiğini ileri sürmektedir (Lévi-Strauss, 2014, s. 71). 
Nazi Almanya'sında Yayıncılık, Nazizm İdeolojisinin Yaydığı Anti-Semitist Söylemlerin İnşası ve Kitapların Propaganda Amaçlı Kullanımı

The Publishing in Nazi Germany, The Construction of Anti-Semitist Discourses Spread by the Nazism Ideology and the Use of Books for the Purpose of Propaganda

\section{Tablo 1}

İkili KarşıtlıklarModeli (Somutlama Modeli) (Fiske, 2017, s. 236).

\begin{tabular}{cc}
\hline Somut Kavramlar & Somut Kavramlar \\
\hline $\mathrm{X}$ & $\mathrm{Y}$ \\
\hline Soyut Kavramlar & Soyut Kavramlar \\
\hline $\mathrm{X} \rightarrow$ Algısal İnşa & $\mathrm{Y} \rightarrow$ Algısal İnşa \\
\hline
\end{tabular}

Çalışmada ilk olarak kitapta yer alan görsel ve yazılı kodlar, Bühler'in modeli üzerinden ele alınarak, kitapta Yahudilere yönelik Alman halkına hangi mesajların verildiği ve Alman halkının Yahudilere yönelik nasıl bir tutuma yönlendirildiklerinin ortaya konulmasına çalışılmıştır. Ardından kitapta Lévi-Strauss'un modeli üzerinden Alman toplumunda Yahudilere yönelik hangi soyut kavramlar yoluyla ikili karşıtlıkların oluşturulduğunun ve hangi mitlerin inşa edildiğinin açıklanması amaçlanmıştır. Bu şekilde incelenen kitap üzerinden Yahudilerin Alman toplumunda nasıl ötekileştirildiğinin ortaya konulmasına çalışılmıştır.

Çalışmada kullanılan Bühler ve Lévi-Strauss'un göstergebilim anlayışları, Nazi Almanya'sında kitap aracılığıyla yürütülen antisemitist propagandaya ışık tutmaktadır. Diğer yandan, gelecek çalışmaların Nazi Almanya'sındaki antisemitist propagandayı farklı göstergebilim modelleri üzerinden de ele alması, konuya ilişkin literatürün zenginleşmesini sağlayabilecektir. Örneğin gelecek çalışmalar, Roland Barthes'ın göstergebilim anlayışı üzerinden Nazi Almanya'sında inşa edilen propaganda mitlerine 1şık tutulabilir. Ya da Nazi Almanya'sındaki antisemitist propaganda, Charles William Morris'in sözdizimsel, anlambilimsel ve edimbilimsel boyutlarında incelebilir.

\section{Bulgular ve Yorum}

Çalışmanın bu kısmında kitabın yer verdiği antisemitist konulardan ön plana çıkan 9 tema çalışma kapsamında incelenmiştir. Bu aşamada hikaye kitabından seçilen 9 bölüm Bühler ve Lévi-Strauss'un modelleri üzerinden ayrı ayrı analiz edilmiştir.

\section{"Yahudi İsmi” Konulu Bölüm}

"Yahudi İsmi" konulu bölümdeki yazılarda Yahudilere Almanya'da verilen isimlere dikkat çekilmektedir. Anlatımsallık işlevi boyutunda incelendiğinde bölümde iki farklı görselin olduğu görülmektedir. Üstte yer alan görselde çocukların bir evin önünde durdukları ve kapıda yazan isimlerine ve ev sakinlerine yöneldikleri anlaşılmaktadır. Altta yer alan görselde ise çocukların bir bahçe çitinde yazan isimlere baktıkları ortaya çıkmaktadır. 


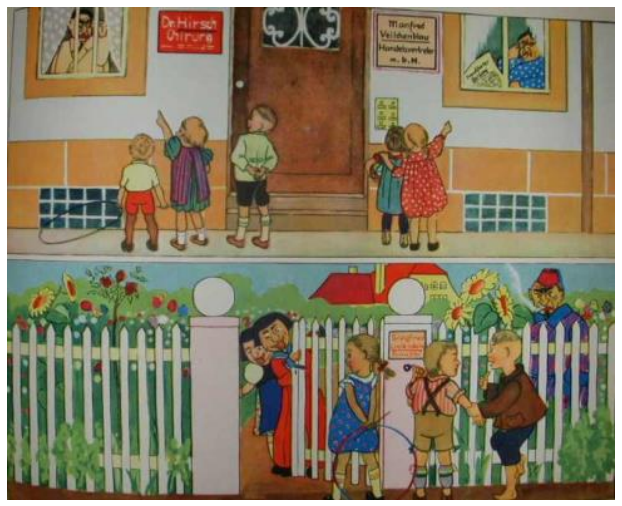

Resim 4. "Yahudi İsmi” Konulu Bölüm (Bauer, 1936).

Temsil işlevi boyutunda ele alındığında kitaptaki yazılardan görselde yer alan çocukların Alman; isimlerini gösterdikleri kişilerin de Yahudi olduğu anlaşılmaktadır. İstem işlevi boyutunda incelendiğinde görselde yer alan kodlardan üzerinden Yahudilerin, Alman toplumundan farklı oldukları mesajının verilmeye çalışıldığı ortaya çıkmaktadır. Yahudilerin, Alman toplumundan doğrudan ayırt edilebilmesi için Yahudiler tarafından kullanıldığı ileri sürülen belirli isimlere vurgu yapılmaktadır. Bu şekilde Almanların, Yahudileri isimlerinden ayırt edebilecekleri mesajı verilmektedir.

\section{Tablo 2}

"Yahudi İsmi" konulu bölümün Organon Modeli’ne göre analizi

\begin{tabular}{cc}
\hline Gösterge & Yahudi isimleri \\
\hline Anlatımsallık İşlevi & Çocukların Yahudi isimlerini göstermesi \\
\hline Temsil İşlevi & Yahudilerin isimleriyle Alman toplumundan ayrıldığı iddiası \\
\hline İstem İşlevi & Yahudilerin Alman toplumuna ait olmadığı algısının meydana gelmesi \\
\hline
\end{tabular}

Somutlama mantığında Almanlar, aidiyet; Yahudiler ise farklılık soyut kavramları üzerinden sunulmaktadır. Bu şekilde bölümde Nazizm ideolojisinde Alman rrkına atfedilen sözde üstünlügün, Yahudilere verilmediği düşüncesi ön plana çıkabilmektedir. Bölümde "Yahudiler Alman halkından farklıdır" şeklindeki Yahudi karşıtı mit inşa edilmektedir. İnşa edilen propaganda mitinde Yahudilerin Alman toplumu içerisinde ötekileştirilmelerinin söz konusu olabileceği ileri sürülebilmektedir. Nazizm ideolojisinin arksal teorisi üzerinden ele alındığında ise Yahudilerin, Alman ırkından olmadığ 1 algısına vurgu yapıldı̆̆ 1 ve isimleri üzerinden onların Alman vatandaşlarından ayrılabileceği mesajının verildiği ortaya çıkabilmektedir. Ortaya konulan farkın "biz" ve "onlar" algısının oluşmasına yol açtığı ileri sürülebilmektedir. 
Nazi Almanya'sında Yayıncılık, Nazizm İdeolojisinin Yaydığı̆ Anti-Semitist Söylemlerin İnşası ve Kitapların Propaganda Amaçlı Kullanımı

The Publishing in Nazi Germany, The Construction of Anti-Semitist Discourses Spread by the Nazism Ideology and the Use of Books for the Purpose of Propaganda

\section{Tablo 3}

"Yahudi İsmi" konulu bölümün İkili Karşıtllklar Modeli’ne göre analizi

\begin{tabular}{cc}
\hline Somut Kavramlar & Somut Kavramlar \\
\hline Alman halk1 & Yahudiler \\
\hline Soyut Kavramlar & Soyut Kavramlar \\
\hline Aidiyet & Farklllık \\
\hline
\end{tabular}

\section{“Çiftlik” Konulu Bölüm}

"Çiftlik" konulu bölümdeki yazılarda Yahudi'nin açgözlü olabileceği iddiasında bulunulmaktadır. Kohn adında altın hırsının ruhunu kararttığı iddia edilen bir Yahudi'den bahsedilmektedir. Bu Yahudi'nin borçlu olan bir çiftçinin inek ve domuzlarını yarı fiyatına aldığını ileri sürmektedir. Yahudi'nin gülerek gittiği, çiftçinin de üzüldüğü anlatılmaktadır. Daha sonra tilkiye ve Yahudi'ye güvenilmemesi belirtilmektedir. Anlatımsallık işlevi boyutunda ele alındığında bir adamın, eli cebinde mutlu bir şekilde inekleri ve domuzları götürdüğü resmedilmektedir. Diğer yandan adamın arkasından yaşlı birinin baktı̆ı aktarılmaktadır.

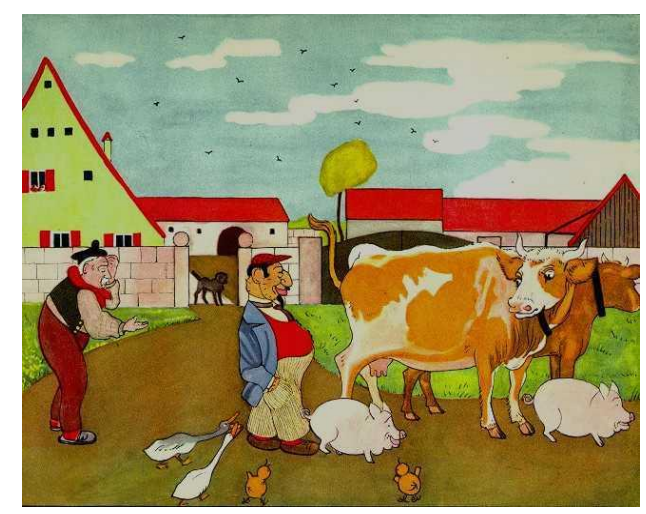

Resim 5. "Çiftlik” Konulu Bölüm (Bauer, 1936).

Temsil işlevi boyutunda incelendiğinde yaşlı çiftçinin Almanların; inek ve domuzları götüren adamın ise Yahudilerin metonimi olarak ön plana çıkarıldığı anlaşılmaktadır. Görselde çiftçinin borçlarından dolayı ineklerini ve domuzlarını değerinin altında Yahudi'ye sattığı aktarılmaktadır. İstem işlevi boyutunda ele alındığında bölümde sözde Yahudilerin, Almanların zor durumlarından yararlanabileceğine ve firsatçıllık yapabileceğine yönelik mesaj verilmektedir. 


\section{Tablo 4}

“Çiftlik” konulu bölümün Organon Modeli’ne göre analizi

\begin{tabular}{cc}
\hline Gösterge & Alman çiftçi \\
\hline Anlatımsallık İşlevi & Yahudi’nin inekleri ve domuzları götürmesi \\
\hline Temsil İşlevi & Yahudilerin insanların zor durumlarından yararlanabileceği iddiası \\
İstem İşlevi & (Sözde) Yahudilerin firsatçı olduğu algısının meydana gelmesi \\
\hline
\end{tabular}

Somutlama mantığında Almanlar, yardımseverlik; Yahudiler ise firsatçılık soyut kavramları üzerinden sunulmaktadır. Yahudiler üzerinden oluşturulan ikili karşıtlıkta Almanların yardımsever insanlar olduğuna ve insanların zor durumlarını kendileri için fırsata çevirmediklerine yönelik alg1 oluşmaktadır. Bölümde "Yahudiler, firsat düşkünüdür" şeklindeki Yahudi karşıtı mit inşa edilmektedir. Yahudilere yönelik inşa edilen bu düşünce Yahudilerin Alman toplumunda istenmeyen kişiler olarak ön plana çıkmasına yol açabilmektedir. Diğer yandan Yahudilerin, Almanların malları üzerinden zenginleşebildiği yönünde de algı meydana gelebilmektedir.

\section{Tablo 5}

“Çiftlik” konulu bölümün İkili Karşıtllklar Modeli’ne göre analizi

\begin{tabular}{cc}
\hline Somut Kavramlar & Somut Kavramlar \\
Alman halkı & Yahudiler \\
Soyut Kavramlar & Soyut Kavramlar \\
Yardımseverlik & Firsatçlık \\
\hline
\end{tabular}

\section{“Merhamet” Konulu Bölüm}

"Merhamet" konulu bölümdeki yazılarda AaronKahn adında yaşlı bir mağaza sahibi Yahudi'den bahsedilmektedir. Tüm değerli malları yalanlarla sattığı ve çantasının oldukça dolu olduğu aktarılmaktadır. Yahudi'nin gözyaşları içinde ekmek için yalvaran aç bir adamı görmesi anlatılmaktadır. Anlatımsallık işlevi boyutunda incelendiğinde görselde başında fes olan bir adamın, yaşı bir adama ve küçük bir çocuğa işaret ettiği görülmektedir.

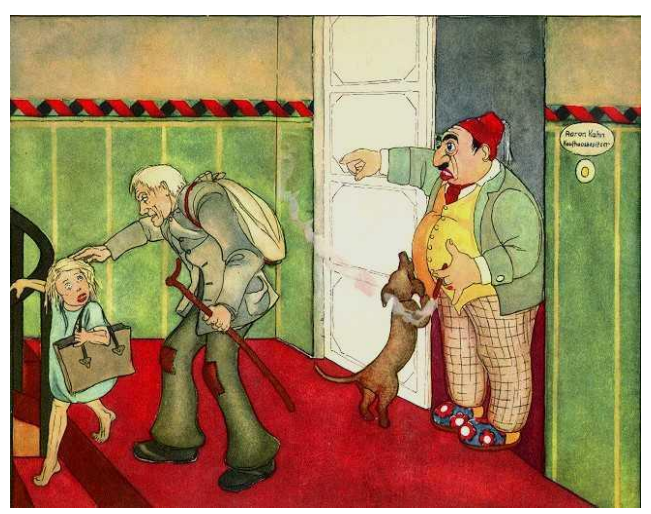

Resim 6. "Merhamet” Konulu Bölüm (Bauer, 1936). 
Nazi Almanya'sında Yayıncılık, Nazizm İdeolojisinin Yaydığı Anti-Semitist Söylemlerin İnşası ve Kitapların Propaganda Amaçlı Kullanımı

The Publishing in Nazi Germany, The Construction of Anti-Semitist Discourses Spread by the Nazism Ideology and the Use of Books for the Purpose of Propaganda

Temsil işlevi boyutunda ele alındığında yaşlı adam ve çocuk Almanların; mağaza sahibi ise Yahudilerin metonimi olarak yansıtılmaktadır. Bölümdeki yazılı ve görsel göstergelerden Yahudi mağaza sahibinin Alman müşterileri sayesinde varlıklı hale geldiği, buna karşılık Almanlara yardım etmediği şeklinde algıların oluşması söz konusu olabilmektedir. İstem işlevi boyutunda incelendiğinde Yahudilerin Almanlara yardım etmediği algısının Alman tüketicilerin nezdinde Yahudi mağaza sahiplerine yönelik olumsuz bir düşüncenin oluşmasına zemin hazırlayabileceği ileri sürülebilmektedir.

\section{Tablo 6}

“Merhamet” konulu bölümün Organon Modeli’ne göre analizi

\begin{tabular}{cc}
\hline Gösterge & Yahudi mağaza sahibi \\
\hline Anlatımsallık İşlevi & Yahudi’nin adama işaret etmesi \\
Temsil İşlevi & Yahudilerin yardımsever olmadığı iddiası \\
\hline İstem İşlevi & (Sözde) Yahudilerin yardımsever olmadı̆̆ı algısının meydana gelmesi \\
\hline
\end{tabular}

Somutlama mantığında Almanlar, merhamet; Yahudiler ise merhametsizlik soyut kavramları üzerinden sunulmaktadır. Yahudilere atfedilen merhametsizlik kavramı üzerinden Almanların merhamet sahibi kimseler olduğu algısı ön plana çıkarılabilmektedir. Bölümde "Yahudiler merhametsizdir" şeklindeki Yahudi karşıtı mit inşa edilmektedir. Yahudilere yönelik oluşturulmaya çalışılan bu mit Yahudilerin Almanlar nezdinde olumsuz bir algıya sahip olmalarına yol açabilmektedir. Bu olumsuz algının, Almanların, Yahudilerden alışveriş yapmada isteksiz olmalarına neden olabileceği ileri sürülebilmektedir.

Tablo 7

“Merhamet” konulu bölümün İkili Karşıtllklar Modeli’ne göre analizi

\begin{tabular}{cc}
\hline Somut Kavramlar & Somut Kavramlar \\
\hline Alman halk1 & Yahudiler \\
\hline Soyut Kavramlar & Soyut Kavramlar \\
\hline Merhamet & Merhametsizlik \\
\hline
\end{tabular}

\section{“Avukat” Konulu Bölüm}

"Avukat” konulu bölümdeki yazılarda çiftçi Michael ve karısının kasabaya gittiği, bir avukatla randevuları olduğu anlatılmaktadır. Çiftçinin iyi giyimli, avukatın çok fakir ve kötü durumda olduğu belirtilmektedir. Yahudi avukatın çiftçiden tereyağ aktarılmaktadır. Avukata yiyecek getirildiği ve avukatın kilo aldığı anlatılmaktadır. Nihayetinde dolandırıcı olduğu iddia edilen Yahudi'nin mallarını ve parasını aldığı belirtilmektedir. Anlatımsallık işlevi boyutunda ele alındığında bölümde iki farklı görselin olduğu ortaya çıkmaktadır. Üstteki görselde bir yazıhanede iki erkek ve bir kadın resmedilmektedir. Görseldeki erkeklerden biri ve kadının, Alman yerel kıyafetleri içerisinde 
oldukları anlaşılmaktadır. Alttaki görselde yine üç kişiye yer verilmekte, buna karşılık üsteki görselde yer alan adamlardan biri, daha kilolu olarak sunulmaktadır.

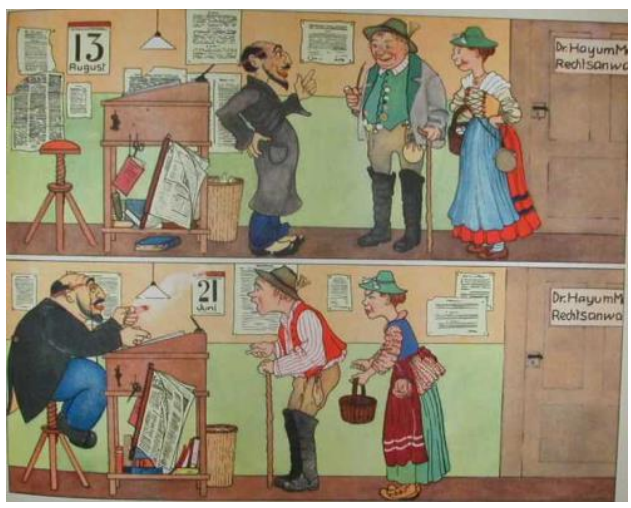

Resim 7. “Avukat” Konulu Bölüm (Bauer, 1936).

Temsil işlevi boyutunda incelendiğinde Yahudi avukata gelen çiftçilerin, giydikleri kıyafetlerden Alman oldukları anlaşılmaktadır. Bu süreçte Yahudi avukatın Yahudileri; çiftçilerin de Almanları temsil ettiği ileri sürülebilmektedir. Yahudi avukatın, Alman çiftçiden belirli şeyler talep etmesi, Yahudilerin Almanları sömürdüğ̈̈ algısının oluşmasına neden olabilmektedir. İstem işlevi boyutunda ele alındığında ise Almanların, Yahudilerle iş yapmaması gerektiğine yönelik düşüncenin oluşabildiği söylenebilmektedir.

\section{Tablo 8}

“Avukat” konulu bölümün Organon Modeli'ne göre analizi

\begin{tabular}{cc}
\hline Gösterge & Yahudi avukat \\
\hline Anlatımsallık İşlevi & Alman çiftin Yahudi avukatın yanına gelmesi \\
Temsil İşlevi & Almanların, Yahudiler tarafından suiistimal edilebileceği iddiası \\
İstem İşlevi & Almanların, Yahudilerle iş yapmaması düşüncesi \\
\hline
\end{tabular}

Somutlama mantığında Almanlar, güven; Yahudiler ise güvensizlik soyut kavramları üzerinden sunulmaktadır. Yahudilere yönelik güvensizlik olgusunun, toplumsal hayatta Yahudilerle iş yapan Almanlarda olumsuz bir algının oluşmasına yol açabileceği ileri sürülebilmektedir. "Yahudiler dolandırıcıdır" şeklindeki Yahudi karşıtı mit inşa edilmektedir. İnşa edilen mit üzerinden Yahudiler doğrudan suçlanmakta ve Almanların Yahudilerle iş yapmaması ve onlardan uzak durması gerektiğine yönelik algı meydana gelebilmektedir. $\mathrm{Bu}$ algının, Almanlar ve Yahudiler arasındaki iş ilişkilerini olumsuz yönde etkileyebileceği belirtilebilmektedir.

Tablo 9

“Avukat” konulu bölümün İkili Karşıtllklar Modeli’ne göre analizi

\begin{tabular}{cc}
\hline Somut Kavramlar & Somut Kavramlar \\
\hline Alman halkı & Yahudiler \\
\hline Soyut Kavramlar & Soyut Kavramlar \\
\hline Güven & Güvensizlik \\
\hline
\end{tabular}


Nazi Almanya'sında Yayıncılık, Nazizm İdeolojisinin Yaydığı Anti-Semitist Söylemlerin İnşası ve Kitapların Propaganda Amaçlı Kullanımı

The Publishing in Nazi Germany, The Construction of Anti-Semitist Discourses Spread by the Nazism Ideology and the Use of Books for the Purpose of Propaganda

\section{“Hizmet” Konulu Bölüm}

"Hizmet" konulu bölümdeki yazılarda hayatını kazanmak için kırları terk eden Rosy adında birinden bahsedilmektedir. Rosy'nin Yahudi Katz'da bir iş bulduğu aktarılmaktadır. Diğer yandan Katz'ın karısı ve çocuklarının tembel kimseler olduğu belirtilmektedir. Kızın burada sıkı bir şekilde çalıştı̆̆ ve Yahudi’ye hizmet ettiği anlatılmaktadır. Anlatımsallık işlevi boyutunda incelendiğinde bir kadının ayakkabıları firçaladığı, diğer kadının da onu izlediği resmedilmektedir.

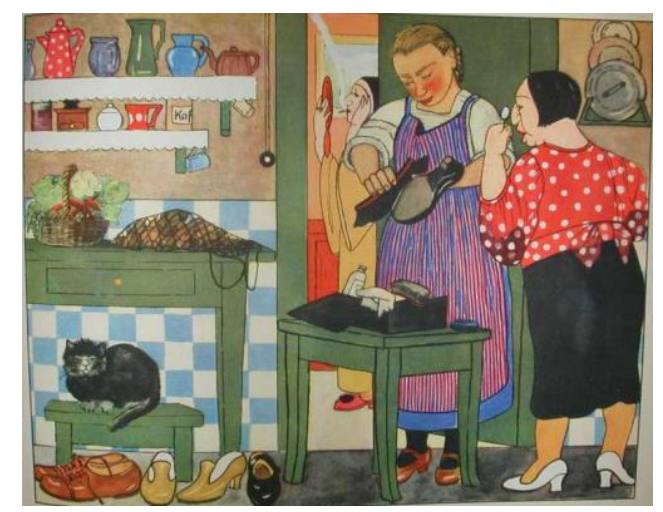

Resim 8. "Hizmet” Konulu Bölüm (Bauer, 1936).

Temsil işlevi boyutunda ele alındığında ayakkabıları fırçalayan kız Almanların; kızı denetleyen kadın ise Yahudilerin metonimi olarak aktarılmaktadır. Çalışkan olarak ifade edilen Almanların, sözde tembel olduğu iddia edilen Yahudiler için çalışması tezat bir durum olarak sunulmaktadır. İstem işlevi boyutunda incelendiğinde Yahudilerin, Almanların emeğini sömürdüğüne yönelik algı oluşabilmektedir. Bu algının Almanların, Yahudilerin yanında çalışma konusunda isteksiz olmalarına neden olabileceği belirtilebilmektedir. $\mathrm{Bu}$ aşamada Yahudilerin, yanında çalışan Almanların, Yahudiler için çalışmayı bırakmasına yönelik bir düşüncenin meydana gelebildiği ileri sürülebilmektedir.

Tablo 10

"Hizmet” konulu bölümün Organon Modeli’ne göre analizi

\begin{tabular}{cc}
\hline Gösterge & Yahudi işveren \\
\hline Anlatımsallık İşlevi & Kızın çalışması \\
\hline Temsil İşlevi & Yahudilerin, Alman emeğini sömürdüğü iddiası \\
\hline İstem İşlevi & (Sözde) Yahudilerin Alman emeğini sömürmesine izin verilmemesi düşüncesi \\
\hline
\end{tabular}

Somutlama mantığında Almanlar, çalışkanlık; Yahudiler ise tembellik soyut kavramları üzerinden sunulmaktadır. Ön plana çıkan soyut kavramlardan Almanların çalışkan olmasına karş1lık sözde tembel olan Yahudilere hizmet ettikleri ileri sürülmektedir. Bu aşamada bölümde "Almanlar, Yahudilere hizmet etmemelidir" şeklindeki Yahudi karşıtı mit inşa edilmektedir. İnşa edilen Yahudi karşıtı propaganda miti üzerinden Almanların, Yahudiler için çalışmasının önüne geçilmesinin amaçlandığı ileri sürülebilmektedir. 


\section{Tablo 11}

“Hizmet” konulu bölümün İkili Karşıtllklar Modeli’ne göre analizi

\begin{tabular}{cc}
\hline Somut Kavramlar & Somut Kavramlar \\
\hline Alman halkı & Yahudiler \\
\hline Soyut Kavramlar & Soyut Kavramlar \\
Çalışkanlık & Tembellik \\
\hline
\end{tabular}

\section{“Alışveriş" Konulu Bölüm}

“Alışveriş" konulu bölümdeki yazılarda bir anne çocuğuna "Yahudi dükkanlarından alışveriş yapmıyoruz" demektedir. Alman kadınlarının Alman eliyle yapılanları satın alması gerektiği belirtilmektedir. Bu nedenle yalnızca sahibi Alman olan mağazalara gidildiği, malları ucuz ve güzel olduğu için buradan daha çok tasarruf edildiği aktarılmaktadır. Annenin sözlerine dikkat edilmesi ve Yahudilerden asla bir şey satın alınmaması anlatılmaktadır. Anlatımsallık işlevi boyutunda ele alındığında görselde bir anne ve kızının bir dükkanın önünden geçtiği resmedilmektedir.

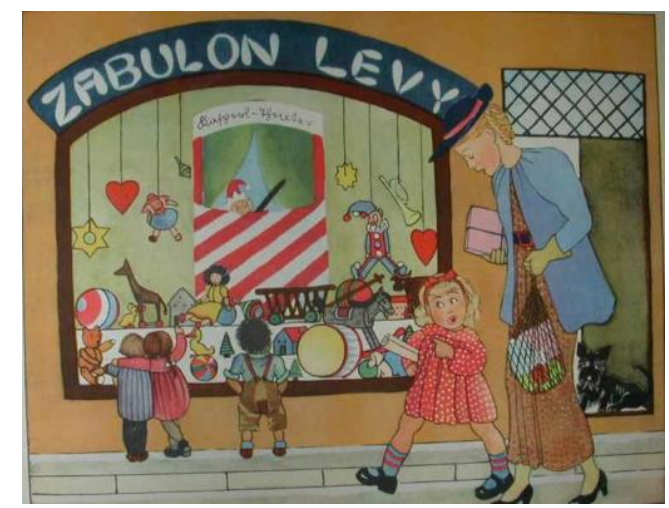

Resim 9. “Alışveriş” Konulu Bölüm (Bauer, 1936).

Temsil işlevi boyutunda incelendiğinde görselde yer alan anne ve çocuğun Almanları temsil ettiği anlaşılmaktadır. Annenin, çocuğuyla konuşması üzerinden Almanların, Yahudiler yerine, Almanlardan alışveriş yapmalarına yönelik mesajın verildiği ortaya çıkabilmektedir. İstem işlevi boyutunda ele alındığında Alman mallarına yönelik olumlu söylem üzerinden Almanların, Almanlardan alışveriş yapmasının teşvik edildiği ileri sürülebilmektedir. Diğer yandan Yahudilerin iş hayatında dışlanmasına da neden olunduğu belirtilebilmektedir.

\section{Tablo 12}

“Allşveriş" Konulu Bölümün Organon Modeli’ne Göre Analizi

\begin{tabular}{cc}
\hline Gösterge & Yahudi esnaf \\
\hline Anlatımsallık İşlevi & Annenin kızıla konuşması \\
\hline Temsil İşlevi & Yahudi malından memnun kalınmayacağı iddiası \\
\hline İstem İşlevi & Yahudi esnaf yerine Alman esnaftan alışveriş yapılması düşüncesi \\
\hline
\end{tabular}


Nazi Almanya'sında Yayıncılık, Nazizm İdeolojisinin Yaydığı̆ Anti-Semitist Söylemlerin İnşası ve Kitapların Propaganda Amaçlı Kullanımı

The Publishing in Nazi Germany, The Construction of Anti-Semitist Discourses Spread by the Nazism Ideology and the Use of Books for the Purpose of Propaganda

Somutlama mantığında Almanlar, aidiyet; Yahudiler ise farklılık soyut kavramları üzerinden sunulmaktadır. Bu soyut kavramlar üzerinden Yahudilerin malları ötekileştirilmekte ve Almanların doğrudan Alman mallarını satın almaları istenmektedir. Bu süreç de Yahudilerin, toplumda dişlanmalarına yol açmaktadır. Bölümde "Yahudilerle alışveriş yapılmaz" şeklindeki Yahudi karşııtı mit inşa edilmektedir. Bu mit üzerinden Almanların, Yahudilerden alışveriş yapmasının önlenmesi söz konusu olabilmektedir. Bu durumda da Yahudilerin mallarını Almanya'da satamamasına ve ülkeyi terk etmesine kadar gidecek süreç meydana gelebilmektedir.

Tablo 13

“Alışveriş̧” konulu bölümün İkili Karşıtllklar Modeli’ne göre analizi

\begin{tabular}{cc}
\hline Somut Kavramlar & Somut Kavramlar \\
\hline Alman halk1 & Yahudiler \\
\hline Soyut Kavramlar & Soyut Kavramlar \\
\hline Aidiyet & Farklılık \\
\hline
\end{tabular}

\section{"Ĕ̈itim” Konulu Bölüm}

"Eğitim" konulu bölümdeki yazılarda bütün Yahudilerin gitmesiyle okullarda sorun olmayacağı belirtilmektedir. Diğer yandan Yahudilerin sızlanmaları ve feryatlarının işe yaramayacağı aktarılmaktadır. Çocuklarla oyun oynayan, onları düzende tutan, şaka yapan, gezen, gülen Alman öğretmeninin arzulandığı ve okula gitmenin büyük bir keyif olduğu belirtilmektedir. Anlatımsallık işlevi boyutunda incelendiğinde görselde bir grup öğrencinin ve bir öğretmenin okuldan ayrılmakta olduğu resmedilmektedir.

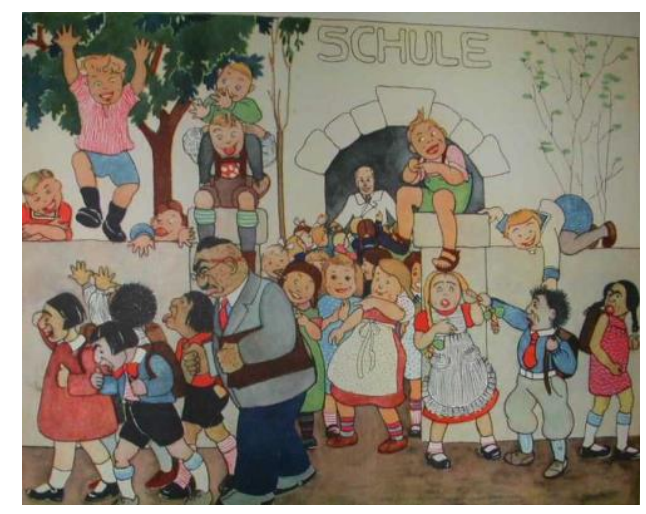

Resim 10. "Eğitim” Konulu Bölüm (Bauer, 1936).

Temsil işlevi boyutunda ele alındığında okuldan ayrılmakta olan öğrenci ve öğretmenlerin Yahudi olduğu anlaşılmaktadır. Görselde yer alan kişilerin doğrudan Yahudileri temsil ettiği belirtilebilmektedir. Bölümdeki görsel ve yazılı kodlardan Yahudilerin Alman okullarında istenmediğine yönelik algının oluşturulduğu ortaya çıkabilmektedir. İstem işlevi boyutunda incelendiğinde Yahudilerin Alman okullarında bulunmalarına izin verilmemesine yönelik düşünce ortaya çıkmaktadır. Bu aşamada Yahudilerin doğrudan Alman eğitiminden uzaklaştırılmalarının desteklendiği belirtilebilmektedir. 
Tablo 14

“Eğitim” konulu bölümün Organon Modeli’ne göre analizi

\begin{tabular}{cc}
\hline Gösterge & Yahudi öğrenciler ve öğretmen \\
\hline Anlatımsallık İşlevi & Yahudi öğretmenin ve öğrencilerin okulu terk etmesi \\
\hline Temsil İşlevi & Yahudi öğretmenlerin ve öğrencilerin okullarda istenmediği iddiası \\
\hline İstem İşlevi & Yahudi öğretmenlerin ve öğrencilerin Alman okullarından uzaklaştırılması \\
düşüncesi
\end{tabular}

Somutlama mantığında Almanlar, aidiyet; Yahudiler ise farklılık soyut kavramları üzerinden sunulmaktadır. Yahudilerin Almanlardan farklı sunulması, onların Alman okullarında istenmediği algısının oluşmasına neden olabilmektedir. Bölümde "Yahudiler, Alman eğitiminden uzaklaştırılmalıdır” şeklindeki Yahudi karşıtı mit inşa edilmektedir. $\mathrm{Bu}$ aşamada Yahudilerin Alman okullarından ayrılmasının olumlu olacağına yönelik algı meydana gelmektedir.

\section{Tablo 15}

“Eğitim” Konulu Bölümün İkili Karşıtlıklar Modeli’ne Göre Analizi

\begin{tabular}{cc}
\hline Somut Kavramlar & Somut Kavramlar \\
\hline Alman halk1 & Yahudiler \\
\hline Soyut Kavramlar & Soyut Kavramlar \\
\hline Aidiyet & Farklılık \\
\hline
\end{tabular}

\section{"Dışlanma” Konulu Bölüm}

"Dışlanma” konulu bölümdeki yazılarda ülkedeki pek çok toprağın güzelliği belirtilmekte, bu nedenle buraların insanların uğrak yeri olduğu aktarılmaktadır. Burada Yahudilerin istenmediği ve burasının sahibinin Almanlar olduğu ileri sürülmektedir. Anlatımsallık işlevi boyutunda ele alındığında bir erkek, bir kadın ve bir çocuğun üzerinde kargaların olduğu bir tabelaya baktığı resmedilmektedir. Tabelada büyük puntolarda "!Juden! sind hier unerwuenscht (Yahudiler! burada istenmiyor)" yazısı yer almaktadır. Görselin arka planında da bir nehir (ya da deniz) kıyıs1 ve tepe görseli bulunmaktadır.

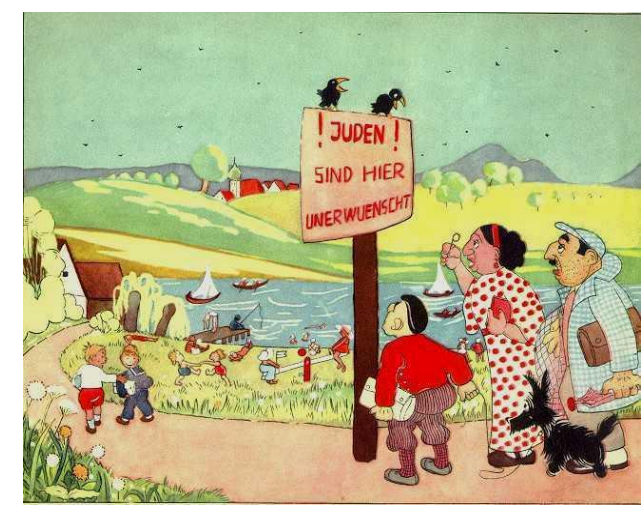

Resim 11. "Dişlanma” Konulu Bölüm (Bauer, 1936). 
Nazi Almanya'sında Yayıncılık, Nazizm İdeolojisinin Yaydığı Anti-Semitist Söylemlerin İnşası ve Kitapların Propaganda Amaçlı Kullanımı

The Publishing in Nazi Germany, The Construction of Anti-Semitist Discourses Spread by the Nazism Ideology and the Use of Books for the Purpose of Propaganda

Temsil işlevi boyutunda incelendiğinde görselde tabelaya bakan kişilerin Yahudi olduğu anlaşılmaktadır. Görselde yer alan kişiler, Almanya'da yaşayan tüm Yahudileri temsil etmektedir. Tabelada bulunan "Yahudiler! burada istenmiyor" söylemi de "Almanya'da Yahudiler istenmiyor" şeklinde algılanabilmektedir. İstem işlevi boyutunda ele alındığında Yahudilerin Almanya' da yeri olmadığına ve ülkeden gitmeleri gerektiğine yönelik düşüncelerin ön plana çıkarılmaya çalışıldığı ileri sürülebilmektedir.

Tablo 16

“Dışlanma” Konulu bölümün Organon Modeli’ne göre analizi

\begin{tabular}{cc}
\hline Gösterge & Yahudi aile \\
\hline Anlatımsallık İşlevi & Yahudilerin tabelaya bakması \\
\hline Temsil İşlevi & Yahudilerin istenmediği iddiası \\
\hline İstem İşlevi & Yahudilerin Almanya'nın doğal güzelliklerinden yararlanmasına izin \\
& verilmemesi düşüncesi \\
\hline
\end{tabular}

Somutlama mantığında Almanlar, aidiyet; Yahudiler ise farklılık soyut kavramları üzerinden sunulmaktadır. Almanya'nın sahibinin Almanlar olduğu ileri sürülmekte ve Yahudiler Almanya'dan dişlanmaktadır. Bu aşamada bölümde "Yahudiler istenmemektedir" şeklindeki Yahudi karşıtı mit inşa edilmektedir. İnşa edilen mit üzerinden Yahudilerin, Almanya'dan gitmesi gerektiğine yönelik düşüncenin oluşabildiği ileri sürülebilmektedir. $\mathrm{Bu}$ şekilde Almanya'da Almanlar ve Yahudilerin birlikte yaşamasına karşı çıkıldığı belirtilebilmektedir.

\section{Tablo 17}

“Dışlanma” konulu bölümün İkili Karşıtllklar Modeli’ne göre analizi

\begin{tabular}{cc}
\hline Somut Kavramlar & Somut Kavramlar \\
\hline Alman halk1 & Yahudiler \\
\hline Soyut Kavramlar & Soyut Kavramlar \\
\hline Aidiyet & Farklılık \\
\hline
\end{tabular}

\section{“Ayrılma” Konulu Bölüm}

"Ayrılma" konulu bölümdeki yazılarda Yahudileri kucaklayan bir ülke olduğundan ve Yahudilerin eşleri ve çocuklarıyla oraya geri dönmesinden bahsedilmektedir. Yahudilerin bulunduğu yerdeki tabelada da "Tek yön yol. Acele acele. Yahudiler bizim talihsizliğimizdir" yazmaktadır. Anlatımsallık işlevi boyutunda incelendiğinde bir grup insanın valizlerle bir yöne doğru ilerlediği aktarılmaktadır. 


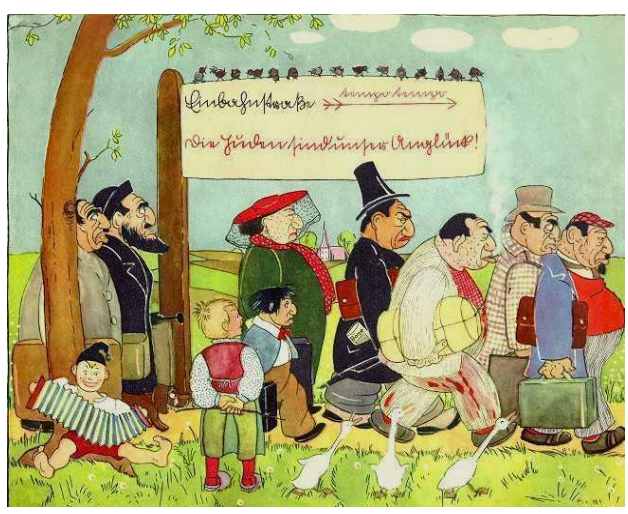

Resim 12. "Ayrilma” Konulu Bölüm (Bauer, 1936).

Temsil işlevi boyutunda ele alındığında görselde bir yöne doğru ilerlemekte olan kişilerin Yahudileri temsil ettiği anlaşılmaktadır. Görselde yer alan tabeladan doğrudan Yahudilerin bir daha geri dönmemek üzere Almanya'dan gitmelerinin istendiği mesajının verildiği ortaya çıkmaktadır. Bu aşamada "Yahudiler bizim talihsizliğimizdir" söylemi, Yahudilerin Almanya'da istenmediği algısının oluşmasına neden olabilmektedir. İstem işlevi boyutunda incelendiğinde Alman halkının Yahudilerin, Almanya'yı terk etmeleri düşüncesine destek vermelerinin istendiği ileri sürülebilmektedir.

Tablo 18

“Ayrllma” konulu bölümün Organon Modeli’ne göre analizi

\begin{tabular}{cc}
\hline Gösterge & Yahudiler \\
\hline Anlatımsallık İşlevi & Yahudilerin bir yöne gitmesi \\
\hline Temsil İşlevi & Yahudilerin, Almanya'dan ayrılmalarının istendiği iddiası \\
\hline İstem İşlevi & Yahudilerin Almanya'dan gönderilmesi düşüncesi \\
\hline
\end{tabular}

Somutlama mantığında Almanlar, aidiyet; Yahudiler ise farklılık soyut kavramları üzerinden sunulmaktadır. Yahudilerin farklı olduğu algısıyla Yahudilerin sözde Almanya'ya ait olmadığ1 algısı bir araya gelmektedir. Bu algılar üzerinden de "Yahudiler, Almanya'dan ayrılmalıdır" şeklindeki Yahudi karşıtı mit inşa edilmektedir. İnşa edilen propaganda mitiyleYahudilerin, Almanya'dan ayrılmasının, Almanların yararına olacağına yönelik düşüncenin meydana gelmesi söz konusu olabilmektedir.

\section{Tablo 19}

“Ayrılma” konulu bölümün İkili Karşıtllklar Modeli’ne göre analizi

\begin{tabular}{cc}
\hline Somut Kavramlar & Somut Kavramlar \\
\hline Alman halk1 & Yahudiler \\
\hline Soyut Kavramlar & Soyut Kavramlar \\
\hline Aidiyet & Farklıllk \\
\hline
\end{tabular}


Nazi Almanya'sında Yayıncılık, Nazizm İdeolojisinin Yaydığı Anti-Semitist Söylemlerin İnşası ve Kitapların Propaganda Amaçlı Kullanımı

The Publishing in Nazi Germany, The Construction of Anti-Semitist Discourses Spread by the Nazism Ideology and the Use of Books for the Purpose of Propaganda

\section{Sonuç}

Çalışmada incelenen kitap özelinde Nazizm ideolojisinin Nazi Almanya'sında yayıncılık faaliyetleri üzerinde doğrudan etkisi olduğu sonucuna ulaşılmaktadır. Nazizm ideolojisinde Yahudilere karşı ön plana çıkan antisemitist söylemlerdeki soyut kavramların kitapta çeşitli hikâyeler yoluyla Yahudiler üzeridensomutlandığı ortaya çıkarılmaktadır. Bu süreçte hikaye kitabında Yahudilerin, öğretmen, avukat, esnaf vb. toplumsal hayattan çeşitli roller üzerinden temsil edildiği görülmektedir. Bölümlerde yer alan yazılı kodlarda Yahudiler bu rollerde olumsuz ifadelerle ve olumsuz soyut kavramlar üzerinden yansitılmaktadır. Yahudilere yer verilen rollerde bu şekilde olumsuz soyut kavramlar üzerinden sunulmalarının, Alman toplumunda Yahudilere yönelik ön yargıların oluşmasına, Yahudilerin ötekileştirilmesine ve hatta dışlanmalarına yol açabileceği ileri sürülebilmektedir.

Hikaye kitabında Yahudilerin, sözde firsat düşkünü, merhametsiz ve dolandırıcı olduğuna yönelik antisemitist propaganda mitleri inşa edilmeye çalışılmaktadır. Bu mitlerin Alman toplumunda Yahudilere yönelik nefret söyleminin gelişmesine neden olabileceğinden söz edilebilmektedir. Ayrıca hikâyede "Almanlar, Yahudilere hizmet etmemelidir" şeklindeki Yahudi karşıtı mit, Yahudilerin Almanların emeklerini sömürdüğüne yönelik algının oluşmasına yol açabilmektedir. Diğer yandan "Yahudilerle alışveriş yapılmaz" şeklindeki diğer bir mitin de Yahudilerin doğrudan dışlanmasının önünü açtığı ileri sürülebilmektedir. Hikaye kitabında yer alan görsel kodlarda da Almanların, Nazizm ideolojisindeki gibi sözde üstün ırk profiline uygun şekilde açık tenli ve sarışın olarak sunulduğu; buna karşıllık Yahudilerin ise esmer, iri burunlu, geniş dudaklı insan stereotipi oluşturularak resmedildiği ortaya çıkmaktadır. Hikaye kitabında Yahudilerin bu şekilde sunulmalarının, Nazizm ideolojisindeki ırksal teorinin meşrulaştırılmasıyla bağlantılı olduğu iddia edilebilmektedir.

Hikaye kitabında Yahudiler, tembellik, güvensizlik, merhametsizlik ve firsatçılık soyut kavramları üzerinden yansıtılmaktadır. Yahudilere yönelik atfedilen soyut kavramlar üzerinden ise Almanlar çalışkanlık, güven, merhamet ve yardımseverlik gibi olumlu soyut kavramlar üzerinden sunulmaktadır. Nazi Almanya'sı özelinde ele alındığında tüm bu süreçte Almanların aidiyet, Yahudilerin ise farklılı olguları üzerinden ön plana çıarıldığından söz edilebilmektedir. Yahudilerin Almanlardan farklı olduğu vurgusu üzerinden Yahudilerin Almanya'da istenmediğine yönelik temel propaganda mitinin hikaye kitabında inşa edilmeye çalışıldığı belirtilebilmektedir. Sonuç olarak Yahudilerin Almanya'da istenmediğine ilişkin mit üzerinden hikaye kitabında Yahudilerin Almanya'dan gönderilmesine yönelik çağrı yapıldığı ileri sürülebilmektedir.

Hikaye kitabı, Nazi Almanya'sında 1935 yılında yürürlüğe konan Nürnberg Yasaları ve 1938 yılında meydana gelen Kristal Gece Olayı arasindaki bir tarihte 1936 yllında yayınlanmaktadır. Bu açıdan hikaye kitabının hem Nürnberg Yasaları'ndaki antisemitizmin meşrulaştırılmasında hem de "Kristal Gece" Olayı'ndaki şiddet eylemlerinin oluşmasında propaganda aracı olarak hizmet ettiği ileri sürülebilmektedir. Nürnberg Yasaları'yla birlikte Yahudilerin, Almanya'daki haklarından bazıları alınmış ve Alman toplumu içerisinde ayrımcılığa maruz kalmalarında önemli bir adım atılmıştır. Bu aşamada hikaye kitabındaki antisemitist söylemlerin, Nürnberg Yasaları'nda alınan kararların sözde doğru olduğuna yönelik algı oluşturulmasına hizmet ettiği söylenebilmektedir. Diğer yandan hikaye kitabındaki 
antisemitist propagandanın insanların Yahudilere yönelik olumsuz algıya sahip olmasına ve “Kristal Gece”Olayı'nda Yahudilere yönelik şiddet eylemlerine giden süreçte Yahudi karşıtlığının güçlenmesine neden olabileceği belirtilebilmektedir.

Nazi Almanya'sında kitap dışında gazete ve dergiler üzerinden de antisemitist propaganda faaliyeti gerçekleştirilmiştir. Buna karşılık kitap, süreli yayınların aksine insanların kütüphanlerinde uzun süre yer alabilmekte, içerisinde yer alan bilgiler gelecek kuşaklara aktarılabilmektedir. $\mathrm{Bu}$ aşamada süreli yayınların aksine Nazilerin kitap üzerinden gerçekleştirdikleri antisemitist propaganda faaliyetlerinin uzun vadeli bir döneme yayılabileceği ileri sürülebilmektedir. Çalışma, ele alınan hikaye kitabı özelinde Nazi Almanya'sında yayıncılık alanında Nazizm propagandasını yansıtması bakımından önem taşımaktadır. Buna karşılık yalnızca kitap özelinde incelemenin yapılması çalışmanın temel sınırlılığını oluşturmaktadır. Bu açıdan gelecek çalışmalarda Nazi Almanya'sında antisemitist yayıncılığın Der Stürmer gazetesi veya LustigeBlätter dergisi üzerinden, mevcut çalışmada elde edilen bulgularla karşılaştırmalı olarak incelenmesinin alana katkı sağlayacağı düşünülmektedir.

\section{Kaynakça}

Adena, M., Enikolopov, R., Petrova, M., Santarosa, V. and Zhuravskaya, E. (2015). Radio and the rise of the Nazis in prewar Germany. The Quarterly Journal of Economics, 130(4), 1885-1939. Doi: 10.1093/qje/qjv030

Bacharach, W. Z. (2007). Antisemitism and racism in Nazi ideology. Berenbaum, M. and Peck, A. J. (Eds.) in The Holocaust and History: The Known, the Unknown, the Disputed, and the Reexamined (p. 64-74). USA: Indiana University Press.

Bankier, D. (1987). The German Communist Party and Nazi antisemitism, 1933-1938. The Leo Baeck Institute Year Book,32(1), 325-340.Doi: 10.1093/leobaeck/32.1.325

Barnes, J. (2014). The righttoread: The book censorship abolition league, 1934-37. Labour History: A Journal of Labour and Social History, (107), 75-93.Doi: 10.3828/labourhistory.107.0075

Bauer, E. (1936). Trau keinem fuchs auf grüner heid und keinem Jud auf seinem eid. Deutschland: Stürmer Verlag.

Bauer, H. (2014). Burning sexual subjects: Books, homophobia and the Nazi destruction of the Institute of Sexual Science in Berlin. Partington, G. And Smyth, A. (Eds.) in Book destruction from the medieval to the contemporary (p. 17-33). London: Palgrave Macmillan.

Beck, H. (2006). Between the dictates of conscience and political expediency: Hitler's conservative alliance partner and antisemitism during the Nazi seizure of power. Journal of Contemporary History,41(4), 611-640.Doi: 10.1177/0022009406067745

Bergen, D. L. (1994). Catholics, Protestants, and Christian antisemitism in Nazi Germany. Central European History, 27(3), 329-348.

Bergen, D. L. (1994). The Nazi concept of 'Volksdeutsche' and the exacerbation of anti-semitism in Eastern Europe, 1939-45. Journal of Contemporary History,29(4), 569-582.Doi: $10.1177 / 002200949402900402$

Biagioli, M. (2002). From book censorship to academic peer review. Emergences: Journal for the Study of Media \& Composite Cultures, 12(1), 11-45.Doi: 10.1080/1045722022000003435

Bosmajian, H. (1986). Censorship and mythmaking in Nazi Germany. Children's Literature, 14(1), 171175.Doi: 10.1353/chl.0.0136

Boyer, P. S. (1963). Boston book censorship in the twenties. American Quarterly, 15(1), 3-24. 
Nazi Almanya’sında Yayıncılık, Nazizm İdeolojisinin Yaydığı Anti-Semitist Söylemlerin İnşası ve Kitapların Propaganda Amaçlı Kullanımı

The Publishing in Nazi Germany, The Construction of Anti-Semitist Discourses Spread by the Nazism Ideology and the Use of Books for the Purpose of Propaganda

Boyer, P. S. (2002). Purity in print: Book censorship in America from the gilded age to the computer age.The United States: University of Wisconsin Press.

Brackman, H. (2000). "A calamity almost beyond comprehension": Nazi anti-semitism and the Holocaust in thethought of WEB Du Bois. American Jewish History,88(1), 53-93.

Bundesarchiv (2020). Naziler Tarafindan Kitapların Yakılması. Erişim Adresi: https://www.bild.bundesarchiv.de/dba/en/search/?yearfrom=\&yearto=\&query=Opernplatz

Carlson, C. L. (2018). Jazz, drama, and a librarian: Advocating against book censorship in public schools. Kansas English,99(1), 8-12.

Connelly, D. S. (2009). To read or not to read: Understanding book censorship. Community \& Junior College Libraries, 15(2), 83-90.Doi: 10.1080/02763910902832222

Çakı, C. (2019). Antisemitist mitlerin inşasında Nazi propagandasının rolü. Karadeniz Teknik Üniversitesi Sosyal Bilimler Enstitüsü Sosyal Bilimler Dergisi, 9(17), 203-219.

Çalışkan, S. (2020). Nazi Almanyası işgali altındaki Sırbistan'da komünizm karşııı kullanılan propaganda posterlerinin göstergebilimsel analizi. Abant Kültürel Araştırmalar Dergisi, 5(9), 96112.

Delfiner, H. (1971). Soviet and Nazi antisemitism. Patterns of Prejudice,5(4), 1-9.Doi: 10.1080/0031322X.1971.9968997

Dunn, D. J. (1984). Pico and beyond: School library censorship controversies. Law Library Journal,77(3), 435-464.

Dussel, K. (2019). "Fotografische allgegenwart?" Hitler-bilder in der presse des NS-staats. Publizistik,64(4), 447-477.

Duthie, F. (2010). Libraries and the ethics of censorship. The Australian Library Journal,59(3), 8594.Doi: 10.1080/00049670.2010.10735994.

Eberle, H. and Uhl, M. (2017). Hitler kitabı. (M. Tüzel, Çev.). İstanbul: Alfa Yayınları.

Edwards, J. (1981). A new twist to an old problem: Recent court decisions on school book censorship. The English Journal,70(3), 50-53.Doi: 10.2307/816865

Ekholm, K. (2001). Political censorship in Finnish libraries from 1944 to 1946. Libraries \& Culture,36(1), 51-57.Doi: 10.1353/lac.2001.0008

Eldridge, S. W. (2006). Ideological incompatibility: The forced fusion of Nazism and Protestant theology and its impact on anti-Semitism in the Third Reich. International Social Science Review,81(3/4), 151-165.

Ficociello, T. (1984). Censorship, book selection, and the marketplace of ideas. Top of the News,41(1), 33-38.

Fishburn, M. (2007). Books are weapons: Wartime responses to the Nazi bookfires of 1933. Book History, 10, 223-251.

Fishburn, M. (2008). The Burning of the books. Fishburn, M. (Ed.), in Burning books (p. 31-48). London: PalgraveMacmillan.

Fiske, J. (2017). İletişim çalışmalarına giriş. (S. İrvan, Çev.). 5. bs. Ankara: Bilim ve Sanat Yayınları.

Fiske, M., and Lowenthal, M. F. (1968). Book selection and censorship: A study of school and public libraries in California. The United States: Univ of California Press.

Foerstel, H. N. (2002). Banned in the USA: A reference guide to book censorship in schools and public libraries. Chicago: Greenwood Publishing Group. 
Frosh, S. (2015). Hate and the 'Jewish science': Anti-Semitism, Nazism and psychoanalysis. Germany: Springer.

Geehr, R., Heineman, J. and Herman, G. (1985). Wien 1910: An example of Nazi anti-semitism. Film \& History: An Interdisciplinary Journal of Film and Television Studies, 15(3), 50-64.

Gillotti, C. F. (1962). Book censorship in Massachusetts: The search for test forobscenity. Boston University Law Review,42(4), 476-491.

Goebbels, J. (2016). Gerçek yüzüyle Komünizm ve teori ve pratikte Bolşevizm. (Z. Köroğlu, Çev.). İstanbul: Bilge Karınca Yayınları.

Gülada, M. O., Gazi, M. A. ve Çakı, C. (2019). Nazi propagandasının ulusal seferberlikte idealize ettiği Alman genç kızları: "Das Deutsche Mädel" dergisi üzerine inceleme. Erciyes İletişim Dergisi, 6(2), 1079-1100. Doi: 10.17680/erciyesiletisim.515202

Hartmann, D. D. (1984). Anti-Semitism and the appeal of Nazism. Political Psychology,5(4), 635642.Doi: $10.2307 / 3791234$

Hausheer, H. (1936). The socio-economic background of nazi antisemitism. Social Forces, 14(3), 341354.

Heilbronner, O. (1990). The role of Nazi antisemitism in the Nazi Party's activity and propaganda: A regional historiographical study. The Leo Baeck Institute Year Book,35(1), 397-439.Doi: 10.1093/leobaeck/35.1.397

Heilbronner, O. (2004). German or Nazi antisemitism?. Stone, D. (Ed.), in The historiography of the Holocaust (p. 9-23). London: Palgrave Macmillan.

Herf, J. (2006). Convergence: the classic case Nazi Germany, anti-semitismand anti-zionism during World War II. The Journal of Israeli History,25(1), 63-83.Doi: 10.1080/13531040500502700

Hett, B. C. (2015). "This story is about something fundamental": Nazi criminals, history, memory, and the Reichstag fire. Central European History,48(2), 199-224. Doi: 10.1017/S0008938915000345

Hogan, R. F. (1967). Book selection and censorship. The Bulletin of the National Association of Secondary School Principals,51(318), 67-77.Doi: 10.1177/019263656705131810

Kater, M. H. (1984). Everyday anti-semitism in prewar Nazi Germany: The Popular Bases. Yad Vashem Studies, 16, 129-59.

Keogh, D. (2006). Irish refugee policy, anti-semitism and Nazism at the approach of World War Two. Holfter, G. (Ed.), in German-speakingexiles in Ireland 1933-1945 (p. 37-73). Holland: Brill Rodopi.Doi: 10.1163/9789401203227_004

Kershaw, I. (2007). Hitler, 1889-1936: Hubris. (Z. Biliz. Çev.). c.1. İstanbul: İthaki Yayınları.

Keskin Yılmaz, Y., Çakı, C. ve Kazaz, A. (2020). Nazi Almanya'sı döneminde Nazizm ideolojisindeki antisemitist propaganda mitlerinin eğitime yansıması. Selçuk Illetişim, 13(3), 1081-1113.

Kidman, S. (2015). Self-regulation through distribution: Censorship and the comic book industry in 1954. The Velvet Light Trap, (75), 21-37.Doi: 10.7560/VLT7503

Kushner, T. (1989). Beyond the pale? British reactionsto Nazi anti-semitism, 1933-39. Immigrants \& Minorities, 8(1-2), 143-160.Doi: 10.1080/02619288.1989.9974712

Lackey, M. (2011). The theology of Nazi anti-semitism in William Styron's Sophie's choice. LIT: Literature Interpretation Theory, 22(4), 277-300.Doi: 10.1080/10436928.2011.622697

Levi, E. (2004). The censorship of musical modernism in Germany, 1918-1945. Müller. B. (Ed.) in Censorship \& cultural regulation in the modern age (p. 61-83). Holland: Brill Rodopi.

Lévi-Strauss, C. (2012). Yapısal antropoloji. (A. Kahiloğlulları, Çev.). Ankara: İmge Yayınları.

Lévi-Strauss, C. (2013). Mit ve anlam. (G. Y. Demir, Çev.). İstanbul: İthaki Yayınları. 
Nazi Almanya’sında Yayıncılık, Nazizm İdeolojisinin Yaydığı Anti-Semitist Söylemlerin İnşası ve Kitapların Propaganda Amaçlı Kullanımı

The Publishing in Nazi Germany, The Construction of Anti-Semitist Discourses Spread by the Nazism Ideology and the Use of Books for the Purpose of Propaganda

Lévi-Strauss, C. (2014). Modern dünyanın sorunları karşısında antropoloji. (A. Terzi, Çev.). İstanbul: Metis Yayınları.

Lévi-Strauss, C. (2016). Irk, tarih ve kültür. (H. Bayrı, R. Erdem, A. Oyacıoğlu, I. Ergüden Çev.). 7. bs. İstanbul: Metis Yayınları.

Lévi-Strauss, C. (2017). Hepimiz yamyamız. (H. Bayrı, Çev.). 2. bs. İstanbul: Metis Yayınları.

Lewy, G. (2016). Harmful and undesirable: Book censorship in Nazi Germany. New York: Oxford University Press.

Littel, F. H. (1971). Kirchenkampf and Holocaust: The German church struggle and Nazi anti-semitism in retrospect. Journal of Church and State, 13(2), 209-226.

Lowenthal, M. F. (1959). Book selection and censorship.The United States: University of California Press.

Mieder, W. (1982). Proverbs in Nazi Germany: The promulgation of anti-semitism and stereotypes through folklore. The Journal of American Folklore,95(378), 435-464.Doi: 10.2307/540750

Nelson, C. (2020). The darkside of Holocaust era poetry: Nazi poetry promoting antisemitism and genocide. Aarons, V. and Lassner, P. (Eds.) in The Palgrave handbook of Holocaust literatüre and culture (p. 357-397). Cham: Palgrave Macmillan.

Niven, B. (2010). Remembering Nazi anti-Semitism in the GDR. Niven, B. and Paver, C. (Eds.) in Memorialization in Germany since 1945 (p. 205-213). London: Palgrave Macmillan.

Oppenheim, C., and Smith, V. (2004). Censorship in libraries. Information Services \& Use,24(4), 159170.Doi: 10.3233/ISU-2004-24401

Panse, B. (1996). Censorship in Nazi Germany. Berghaus, G. (Ed.) in Fascism and theatre: comparative studies on the aesthetics and politics of performance in Europe, 1925-1945 (p. 140-156). The United States: Berghahn Books.

Ravenwood, C., and Feather, J. (2010). Censorship and book selection in British Public Librarianship 1919-1939: Professional perspectives. Library \& Information History,26(4), 258-271.Doi: $10.1179 / 175834910 X 12816060984395$

Reimer, C., and Brock, M. (1988). Books, students, censorship: Reality in the classroom. The English Journal,77(7), 69-71.Doi: 10.2307/818944

Ribbens, K. (2018). Picturing anti-semitism in the Nazi-occupied Netherlands: anti-Jewish stereotyping in a racist Second World War comic strip. Journal of Modern Jewish Studies,17(1), 8-23.Doi: 10.1080/14725886.2017.1380976

Ritchie, J. M. (1988). The Nazi book-burning. The Modern Language Review,83(3), 627-643. Doi: $10.2307 / 3731288$

Rodrìguez, M. G. (2003). Behind Lenis outlook: A perspective on the film Olympia (1938). International Review for the Sociology of Sport,38(1), 109-116.

Roncelli, J. M. (1983). Book censorship: A strategy of order for the firemen in Fahrenheit 451 and moral majority, Inc. Free Speech Yearbook, 22(1), 20-32.Doi: 10.1080/08997225.1983.10556024

Sabato, M. (2014). Comparing book censorship: An Italian and European perspective (Centuries XVIXVIII). European Scientific Journal,10(22), 53-68.

Samuels, A., Shamdasani, S., Heuer, G. and Von Der Tann, M. (1993). New material concerning Jung, anti-semitism, and the Nazis. Journal of Analytical Psychology,38(4), 463-470.

Selth, J. P. (1993). Ambition, discrimination and censorship in libraries. North Carolina: McFarland \& Co. 
Seul, S. (2013). 'Herr Hitler's Nazis hear an echo of worldopinion': British and American press responses to Nazi anti-semitism, September 1930-April 1933. Politics, Religion \& Ideology, 14(3), 412-430.Doi: 10.1080/21567689.2013.820453

Shain, M. (2015). Echoes of Nazi antisemitism in South Africa during the 1930s and 1940s. Browning, C. R., Heschel. S., Marrus, M. R. and Shain, M. (Eds.) in Holocaust scholarship (p. 215-238). London: Palgrave Macmillan.

Smith, E. E. (1955). Constitutional aspects of book censorship. Dicta,32(5), 305-311.

Smith, R. B. (1998). Anti-semitism and Nazism: reconciling fromm and goldhagen. American Behavioral Scientist,41(9), 1324-1362.Doi: 10.1177/0002764298041009009

Sonesson, G. (2016). The phenomenological semiotics of iconicity and pictoriality-including some replies to my Critics. Language and Semiotic Studies,2(2), 1-73.

Steinweis, A. E. (2006). Studying the Jew: scholarly antisemitism in Nazi Germany. The United States: Harvard University Press.

Stelmakh, V. D. (2001). Reading in the context of censorship in the Soviet Union. Libraries \& Culture, $36(1), 143-151$.

Stielow, F. J. (1983). Censorship in the early professionalization of American libraries, 1876 to 1929. The Journal of Library History (1974-1987), 18(1), 37-54.

Stover, M. (1994). Libraries, censorship, and social protest. American Libraries,25(10), 914-916.

Sturge, K. (2002). Censorship of translated fiction in Nazi Germany. TTR: Traduction, Terminologie, Rédaction,15(2), 153-169.Doi: 10.7202/007482ar

Thurlow, R. (1984). Anti-Nazi antisemite: the case of Douglas Reed. Patterns of Prejudice,18(1), 2334.Doi: 10.1080/0031322X.1984.9969740

Urrieta, L., and Machado-Casas, M. (2013). Book banning, censorship, and ethnic studies in urban schools: An introduction to the special issue. The Urban Review, 45(1), 1-6.Doi: 10.1007/s11256012-0221-6.

USHMM (2020). Berlin Cinsel Araştırma Enstitüsü Direktörü Dr. Magnus Hirschfeld'in Kütüphanesine Müdahale. Erişim Adresi: https:// collections. ushmm. org/ search/ catalog/ pa26351

Voigtländer, N., and Voth, H. J. (2012). Persecution perpetuated: the medieval origins of anti-semitic violence in Nazi Germany. The Quarterly Journal of Economics,127(3), 1339-1392.Doi: 10.1093/qje/qjs019

VonBieberstein, J. R. (1977). The story of the Jewish-Masonic conspiracy, 1776-1945. Patterns of Prejudice,11(6), 1-21. Doi: 10.1080/0031322X.1977.9969409.

Wegner, G. (2014). Anti-Semitism and schooling under the Third Reich. The United Kingdom: Routledge.

Weinstein, V. (2019). Antisemitism in film comedy in Nazi Germany. The United States: Indiana University Press.

Zuschlag, C. (1997). "Chambers of horrors of art" and "degenerate art": on censorship in the visual arts in Nazi Germany". Childs, E. C. (Ed.) in Suspended license: censorship and the visual arts, (p. 210-234). Washington: University of Washington Press.

\section{Summary}

The Nazi regime aimed to control the media in order to gain strict control over German people and to impose the ideological discourses of Nazism on the masses. For this purpose, the Ministry of Public Enlightenment and Propaganda, under the leadership of Dr. Joseph Goebbels, one of the leading names of the National Socialist German Workers Party (NSDAP), 
Nazi Almanya'sında Yayıncılık, Nazizm İdeolojisinin Yaydığı Anti-Semitist Söylemlerin İnşası ve Kitapların Propaganda Amaçlı Kullanımı

The Publishing in Nazi Germany, The Construction of Anti-Semitist Discourses Spread by the Nazism Ideology and the Use of Books for the Purpose of Propaganda

was established. During his ministry Goebbels established strict control over the German media and didn't allow broadcasts considered as a threat to the Nazi regime. The censorship imposed by the Nazi regime prevented any dissident broadcast in Nazi Germany. The Nazis didn't allow opposing ideas to gain power in German society and sought to dominate the Nazism ideology in German society through censorship. During this period, book publishing and libraries in Germany also came under the control of the Nazis and Franz Eher Nachfolger came to the fore in the field of publishing. Franz Eher Nach folger GmbH assumed the role of NSDAP's central publishing house and became one of the largest book and periodical publishing companies during the Nazi Germany. It was responsible for the printing of Völkischer Beobachter, one of the main newspapers in Nazi Germany. Adolf Hitler's Mein Kampf book was also published by this publishing house. Publications on the Nazism ideology began to come to the fore in the country with the dominance of the Nazi regime in broadcasting. In these publications, efforts were made to exalt the Nazism ideology and to build Hitler's leadership cult. The anti-Semitic teachings of the Nazism ideology were also presented to the masses through publications. At this stage, the censorship applied in Nazi Germany prevented the publications that opposed the anti-Semitic discourses of the Nazi ideology.

It was aimed to reveal the reflections of the Nazism ideology in the field of publishing in Nazi Germany, in particular the anti-Semitic discourses in the Nazism ideology in the study. For this purpose, the anti-Semitist book called Trust No Fox on his Green Heath and No Jew on his Oath (Trau keinem Fuchs auf grüner Heid und keinem Jud auf seinem Eid), published during the Nazi Germany, was examined using the semiotics method.

The aim of the study is to answer the following questions;

- How are the anti-Semitic discourses in the Nazism ideology reflected in the book?

- By what visual and written codes are Jews represented in the book?

- What anti-Jewish myths are attempted to form in German society through the book?

- What abstract concepts are compared between German citizens and Jews in the book?

The study is important in terms of providing information on publishing during the Nazi Germany and explaining the use of the book for propaganda purposes in the adoption of the Nazism ideology to the masses. It was aimed to enlighten how books can be used for propaganda purposes in the dimension of ideological discourses in the light of the findings of the study. All the boks used for antisemitic propaganda during the Nazi Germany constitute the universe of the study. At this stage, two books on anti-Semitism in Nazi Germany standout: The Poisonous Mushroom (Der Giftpilz) and Trust No Fox on his Green Heathand No Jew on his Oath (Trau keinem Fuchs auf grüner Heid und keinem Jud auf seinem Eid). It was revealed that the Poisonous Mushroom book was discussed in different studies in the examination made within the scope of the study. In this respect, the study was carried out through the book called Trust No Fox on his Green Heath and No Jew on his Oath, which was not previously discussed.

Within the scope of the study, German linguist Karl Bühler's Organon Model was used to reveal the actual dimensions in the book. On the other hand French anthropologist Claude Lévi-Strauss' Binary Oppositions Model was used in order to reveal the binary opposites and myths in the book. In the study, firstly, the visual and writtenc odes in the book were examined 
through Bühler's model and it was tried to reveal what messages were given to the German people in the book and what kind of attitude the German people were directed towards Jews. Then, it was aimed to explain by which abstract concepts for Jews were formed in German society and which myths were constructed in the book through the model of Levi-Strauss. In this way, it was tried to reveal how the Jews were marginalized in German society through the book examined.

It was concluded that the Nazism ideology had a direct effect on publishing activities in Nazi Germany in the book examined in the study. It was revealed that the abstract concepts in the anti-Semitic discourses that came to the fore against the Jews in the Nazism ideology were concreted on the Jews through various stories in the book. In this process, it was seen that Jews were represented in the story book through various roles from social life such as teachers, lawyers and shopkeepers. In the written codes in the chapters, Jews were reflected in these roles with negative expressions and through negative abstract concepts. It can be argued that the presentation of Jews through negative abstract concepts in roles may lead to the formation of prejudices against the Jews in German society, the marginalization of the Jews and even their exclusion.

In the story book, antisemitic propaganda myths that show that Jews are opportunistic, ruthless and fraudulent were attempted to be constructed. It can be mentioned that these myths may cause the development of hate speech against Jews in German society. In the story book, the Jews were reflected through abstract concepts such as laziness, distrust, ruthlessness and opportunism. Over the abstract terms attributed to the Jews, Germans were presented through positive abstract concepts such as diligence, trust, compassion and benevolence. When considered in the context of Nazi Germany, it can be mentioned that the Germans were brought to the fore through the phenomena of belonging and the Jews were brought to the fore through the phenomena of difference. With the emphasis that Jews were different from Germans, it can be stated that the main propaganda myth that Jews weren't wanted in Germany was tried to be constructed in the story book. As a result, it can be argued that the story book calls for the removal of Jews from Germany based on the myth that Jews weren't wanted in Germany. 